\title{
Assessing Cadmium and Chromium Concentrations in Drinking Water to Predict Health Risk in Malaysia
}

\author{
Minhaz Farid Ahmed and Mazlin Bin Mokhtar* \\ Institute for Environment and Development (LESTARI), Universiti Kebangsaan Malaysia (UKM), UKM Bangi, \\ Selangor 43600, Malaysia; minhaz@ukm.edu.my \\ * Correspondence: mbmlestari@hotmail.com; Tel.: +603-8921-4149
}

Received: 16 January 2020; Accepted: 1 March 2020; Published: 24 April 2020

\begin{abstract}
Although toxic $\mathrm{Cd}$ (cadmium) and $\mathrm{Cr}$ (chromium) in the aquatic environment are mainly from natural sources, human activities have increased their concentrations. Several studies have reported higher concentrations of $\mathrm{Cd}$ and $\mathrm{Cr}$ in the aquatic environment of Malaysia; however, the association between metal ingestion via drinking water and human health risk has not been established. This study collected water samples from four stages of the drinking water supply chain at Langat River Basin, Malaysia in 2015 to analyze the samples by inductivity coupled plasma mass spectrometry. Mean concentrations of $\mathrm{Cd}$ and $\mathrm{Cr}$ and the time-series river data (2004-2014) of these metals were significantly within the safe limit of drinking water quality standard proposed by the Ministry of Health Malaysia and the World Health Organization. Hazard quotient (HQ) and lifetime cancer risk (LCR) values of Cd and Cr in 2015 and 2020 also indicate no significant human health risk of its ingestion via drinking water. Additionally, management of pollution sources in the Langat Basin from 2004 to 2015 decreased $\mathrm{Cr}$ concentration in 2020 on the basis of autoregression moving average. Although $\mathrm{Cd}$ and $\mathrm{Cr}$ concentrations were found to be within the safe limits at Langat Basin, high concentrations of these metals have been found in household tap water, especially due to the contamination in the water distribution pipeline. Therefore, a two-layer water filtration system should be introduced in the basin to achieve the United Nations Sustainable Development Goals (SDGs) 2030 agenda of a better and more sustainable future for all, especially via SDG 6 of supplying safe drinking water at the household level.
\end{abstract}

Keywords: Malaysia; Langat River Basin; drinking water; hazard quotient; lifetime cancer risk

\section{Introduction}

Cadmium $(\mathrm{Cd})$ and Chromium $(\mathrm{Cr})$ in the aquatic environment are mainly from the erosion of natural deposits [1,2], but can also be a result of discharge from metal refineries and runoff from waste batteries and paints [3-6]. The detrimental impact of toxic $\mathrm{Cd}$ and $\mathrm{Cr}$ on living organisms in the aquatic environment is due to their prolonged persistence and non-biodegradable characteristics $[7,8]$. Therefore, these metals have been listed as the toxic trace metals by the United States Environmental Protection Agency (USEPA) if ingested via drinking water. The natural weathering of mineral rocks is considered as the main source of $\mathrm{Cd}$ and $\mathrm{Cr}$ in the Langat River, Malaysia $[9,10]$. Low concentration of dissolved Cd $\left(1 \times 10^{-3} \mathrm{mg} / \mathrm{L}\right)$ was reported by Mamun et al. [11] in the Langat River; however, Sarmani [12] and Yusuf [13] observed very high concentration of Cd in Langat River $\left(35.56 \times 10^{-3} \mathrm{mg} / \mathrm{L}\right.$ and $24 \times 10^{-3} \mathrm{mg} / \mathrm{L}$, respectively). The high concentration of $\mathrm{Cd}$ in Langat River might be because of sampling locations near ex-mining sites and runoff from infrastructure development activities within the Langat Basin. Similarly, Wang et al. [14] found high dissolved Cd concentration $\left(61.74 \times 10^{-2} \pm\right.$ $\left.90.12 \times 10^{-2} \mathrm{mg} / \mathrm{L}\right)$ in the Huaihe River, China. Aris et al. [9] reported a low $\mathrm{Cr}$ concentration $\left(6.7 \times 10^{-4}\right.$ $\left.\pm 9 \times 10^{-4} \mathrm{mg} / \mathrm{L}\right)$ in the Langat River; however, higher $\mathrm{Cr}$ concentration was recorded $\left(7 \times 10^{-2} \mathrm{mg} / \mathrm{L}\right)$ 
in Langat River [13]. Islam et al. [7] also reported high $\mathrm{Cr}$ concentration $\left(7.8 \times 10^{-2} \pm 2.7 \times 10^{-4} \mathrm{mg} / \mathrm{L}\right)$ in the Korotoa River, Bangladesh.

The corrosion of galvanised pipes is also attributed to higher concentration of $\mathrm{Cd}$ and $\mathrm{Cr}$ in the tap/drinking water globally, including in Malaysia [15,16]. For instance, Ong et al. [17] reported Cd concentrations of $1.33 \times 10^{-3} \mathrm{mg} / \mathrm{L}$ and $\mathrm{Cr} 1.24 \times 10^{-3} \mathrm{mg} / \mathrm{L}$ in the tap water of Kuala Lumpur, Malaysia. Similarly, Nalatambi [16] found the concentrations of $\mathrm{Cd}$ to be $1.3 \times 10^{-5} \mathrm{mg} / \mathrm{L}$ and $\mathrm{Cr} 6.75$ $\times 10^{-3} \mathrm{mg} / \mathrm{L}$ in the tap water at Sunway Kuala Lumpur, Malaysia. Low levels of Cd $\left(4.1 \times 10^{-5} \pm\right.$ $1 \times 10^{-5} \mathrm{mg} / \mathrm{L}$ [18] and $2 \times 10^{-5} \pm 1 \times 10^{-5} \mathrm{mg} / \mathrm{L} \mathrm{[19])} \mathrm{and} \mathrm{Cr}\left(8 \times 10^{-3} \pm 4 \times 10^{-4} \mathrm{mg} / \mathrm{L} \mathrm{[19])} \mathrm{have}\right.$ also been reported in the Langat River Basin, Malaysia. Langat River is one of the main sources of drinking water in the State of Selangor, Malaysia, providing drinking water to almost one-third of the population in the state [20-22]. However, no studies in Malaysia have linked the association between $\mathrm{Cd}$ and $\mathrm{Cr}$ ingestion via drinking water and human health risk.

The association between $\mathrm{Cd}$ exposure and renal cancer has been reported by studies in Thailand [23], China [24], the USA [25-27], and Europe [28-30]. Cadmium is highly toxic and highly soluble in water [31,32], so even at low levels (i.e., $1 \times 10^{-3} \mathrm{mg} / \mathrm{L}$ ) the ingestion of cadmium via drinking water may cause acute gastroenteritis [33], renal tubular dysfunction, and renal cancer [34,35], as well as histopathological changes in humans [36]. Therefore, humans are very susceptible to the acute toxicity of Cd ingestion via drinking water because of its 10-35 year biological half-life [37,38] as well as its bioavailability and bio accumulative characteristics [27,39]. Hence, $\mathrm{Cd}$ is classified as a human carcinogenic (Group 2A) by the International Agency for Research on Cancer [31] and the European Commission [40] on the basis of human and animal experiments. In addition to carcinogenic impacts of $\mathrm{Cd}$ exposure, non-carcinogenic impacts such as chronic kidney disease (CKD), hypertension, diabetes, bone defects, and macular degeneration have been observed [23-44].

On the other hand, $\mathrm{Cr}$ is naturally found in environmental media originating both from ingenious geologic formations and anthropogenic activities [2,45]. Chromium is also highly soluble in water and has prolonged persistence in the environment [46]. Therefore, both the IARC (International Agency for Research on Cancer) and USEPA have classified $\mathrm{Cr}(\mathrm{VI})$ as a group 1 human carcinogen because of its acute toxicity via ingestion [47-49]. The carcinogenic characteristics of $\mathrm{Cr}(\mathrm{VI})$ are based on laboratory experiments on animal stomachs, intestinal tracts, and lung [50,51]. Therefore, human epidemiology is required to find out the association between $\mathrm{Cr}$ ingestion via drinking water and various forms of cancer $[52,53]$. Meanwhile, several studies have reported the association between the lung cancer of workers in the USA and the inhalation of Cr (VI) [54]. The U.S. National Institute for Occupational Safety and Health has estimated that the lifetime risk of lung cancer death at exposure to $1 \times 10^{-6} \mathrm{mg} / \mathrm{L}$ $\mathrm{Cr}(\mathrm{VI})$ is 6 per 1000 workers; exposure to $2 \times 10^{-7} \mathrm{mg} / \mathrm{L} \mathrm{Cr}(\mathrm{VI})$ has been estimated to be approximately 1 lung cancer death per 1000 workers [55]. Similarly, $\mathrm{Cr}$ (VI) was detected in about one-third of 7000 drinking water sources surveyed by the State of California in the USA (detection limit $1 \times 10^{-3} \mathrm{mg} / \mathrm{L}$ ), although the reported concentrations of $\mathrm{Cr}$ (VI) was relatively low $\left(86 \%<1 \times 10^{-2} \mathrm{mg} / \mathrm{L}\right)$ [56]. It is suspected that about 200 million people in USA across all the 50 states have been exposed to higher than recommended levels of $\mathrm{Cr}(\mathrm{VI})$ through their tap water; therefore, they are susceptible to more than 12,000 new cases of cancer in 2014 [57,58]. Beaumont et al. [56] reported that ingestion of $\mathrm{Cr}(\mathrm{VI})$ via drinking water is possibly associated with stomach cancer in China. Non-carcinogenic risks of $\mathrm{Cr}$ (VI) exposure include diarrhea, stomach and intestinal bleeding, cramps, liver damage, and kidney damage $[59,60]$. This study determined the $\mathrm{Cd}$ and $\mathrm{Cr}$ status in the drinking water supply chain at the Langat River Basin, Malaysia. Additionally, predictions are made on the potential human health risk of $\mathrm{Cd}$ and $\mathrm{Cr}$ ingestion to suggest better management of drinking water. 


\section{Materials and Methods}

\subsection{Water Quality Determination}

Water samples were collected one time in 2015 from the four stages of drinking water supply chain (i.e., river water, water treatment plant (WTP), household (HH) tap water, and post- filtration water) at Langat River Basin, Malaysia. Three replicates of water samples were collected from the eight points of Langat River where the WTPs collect water for drinking water treatment purposes. Three replicates of water samples were also collected from the outlets of the eight WTPs. Three replicates of household tap water and post-filtration filtered water samples were also collected on the basis of the five types of water filtration systems in the same households (Figure 1). A Chelex 100 resin column ion-exchange method was applied to analyze the dissolved $\mathrm{Cd}$ and $\mathrm{Cr}$ concentrations in the water samples [61,62] by the inductive coupled plasma mass spectrometry (ICP-MS). Standards of several concentrations were prepared to calibrate the analysis of these metals by ICP-MS. Blanks were also prepared to avoid the error in the results of metal concentrations. Multi-element calibration standard III (PerkinElmer, Lot \#CL7-173YPY1, PE \#N9300233) was used for the recoveries of the standard reference material (SRM); it was calculated for $\mathrm{Cd}$ at $94.966 \% \pm 0.295 \%$ and $\mathrm{Cr}$ at $99.803 \% \pm 0.005 \%$. ANOVA was performed using SPSS software (IBM Corp., Armonk, NY, USA, Version 21.0) to compare Cd and Cr concentrations among the four stages of drinking water supply chain and among the sampling locations in the Langat River Basin.

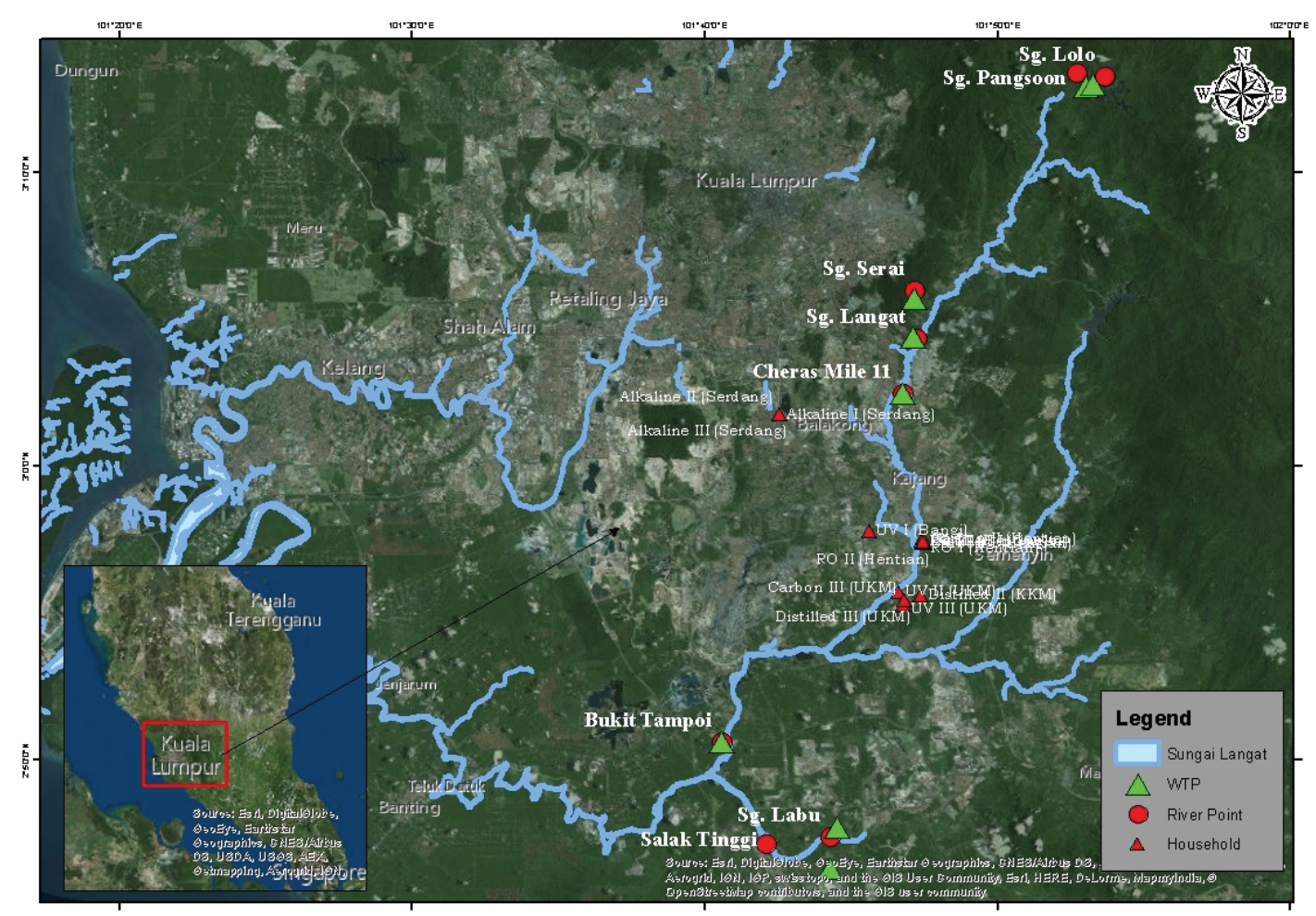

Figure 1. Water sampling locations in the Langat River Basin, Malaysia.

\subsection{Human Health Risk Assessment}

The USEPA has listed $\mathrm{Cd}$ and $\mathrm{Cr}$ as highly toxic contaminants that can have cancer risks if ingested for a long period of time $[32,47,63]$. Therefore, to assess the human health risk, the USEPA established a model of chronic daily intake (CDI) of chemicals [64], non-carcinogenic hazard quotient (HQ), and carcinogenic lifetime cancer risk (LCR) [3] based on Cd and Cr ingestion via drinking water [63,65].

$$
\mathrm{CDI}(\mathrm{mg} / \mathrm{kg}-\text { Day })=[\mathrm{Cdw}(\mathrm{mg} / \mathrm{L}) \times \mathrm{IR}(\mathrm{L} / \text { Day }) \times \mathrm{EF}(\text { Day/Year }) \times \mathrm{ED}(\text { Years })] /[\mathrm{BW}(\mathrm{kg}) \times \mathrm{AT}(\text { Days })]
$$




$$
\begin{gathered}
\mathrm{HQ}=[\mathrm{CDI}(\mathrm{mg} / \mathrm{kg}-\text { Day })] /[\mathrm{RfD}(\mathrm{mg} / \mathrm{kg}-\text { Day })] \\
\mathrm{LCR}=[\mathrm{CDI}(\mathrm{mg} / \mathrm{kg}-\text { Day })] \times\left[\mathrm{SF}(\mathrm{mg} / \mathrm{kg}-\text { Day })^{-1}\right]
\end{gathered}
$$

Here:

$\mathrm{CDI}=$ chronic daily intake $(\mathrm{mg} / \mathrm{kg}$-day);

$\mathrm{Cdw}=$ metal concentration in water $(\mathrm{mg} / \mathrm{L})$;

$\mathrm{IR}=$ water ingestion rate (1.996 L/day; questionnaire survey);

$\mathrm{EF}=$ exposure frequency $(365$ day/year $[3,63])$;

$\mathrm{ED}=$ exposure duration (74 years [3]);

BW = body weight $(63.193 \mathrm{~kg}$; questionnaire survey);

$\mathrm{AT}=$ average time $(27,010$ days $[3,63])$.

The upper bound range of lifetime cancer risk (LCR) to an individual is $10^{-4}$ to $10^{-6}$. Most highly exposed populations should not exceed $10^{-5}$ risk level; however, if cancer risk value is greater than $10^{-5}$, then action must be taken to protect the populations [65]. Similarly, any value of hazard quotient $(H Q) \geq 1$ should be taken seriously to avoid non-carcinogenic risks to humans $[3,65]$. Therefore, the chronic daily intake (CDI) of $\mathrm{Cd}$ and $\mathrm{Cr}$ at Langat Basin, Malaysia was calculated through Equation (1). The HQ and LCR values were calculated according to Equations (2) and (3), respectively, using the RfD (oral reference dose) of $\mathrm{Cd}\left(5 \times 10^{-4} \mathrm{mg} / \mathrm{kg}\right.$-day) [66] and $\mathrm{Cr}\left(3 \times 10^{-3} \mathrm{mg} / \mathrm{kg}\right.$-day) [67], as well as the slope factor value of $\mathrm{Cr}\left(5 \times 10^{-1}(\mathrm{mg} / \mathrm{kg}\right.$-day) [67].

\subsection{Household Questionnaire Survey}

According to the latest population census by the Department of Statistic Malaysia, the total number of households in the Langat River Basin is 1,494,865 [68]. A 402-household questionnaire survey was conducted at the basin using Equation (IV) $[69,70]$ to obtain the average daily drinking water intake by the population in the basin. Additionally, the body weight of household members was used to calculate the CDI of $\mathrm{Cd}$ and $\mathrm{Cr}$ ingestion through drinking water.

$$
n=\left[N /\left(1+N(\mathrm{e})^{2}\right)\right]
$$

Here:

$n=$ sample size;

$N$ = population size;

$\mathrm{e}=$ level of precision $(0.05$ at $95 \%$ confidence level).

\subsection{Prediction Model of Metal Concentration in Water}

Time series (2005-2014) monthly Langat River water quality data for $\mathrm{Cd}$ and $\mathrm{Cr}$ were provided by the Department of Environment (DOE) Malaysia. Therefore, the time series auto regression moving average statistical analysis was applied to estimate $\mathrm{Cd}$ and $\mathrm{Cr}$ concentration models in January 2020 on the basis of DOE (2005-2014) and laboratory data (2015-2016) [71-73]. Moreover, the assumptions of time series data analysis were fulfilled with a significant augmented Dickey-Fuller (ADF) unit root test for these metals at 0.01 level. Assumptions were also confirmed through autocorrelation (PACF) and partial autocorrelation (PACF) plots at 95\% confidence level.

\section{Results and Discussions}

\subsection{Metal Concentrations in Drinking Water Supply Chain}

Concentrations of $\mathrm{Cd}$ and $\mathrm{Cr}$ in the drinking water supply chain (Table 1 ) at the Langat River basin, Malaysia, were within the drinking water quality standards of Ministry of Health Malaysia $(\mathrm{MOH})$, World Health Organization (WHO), USEPA, and European Commission (EC). The skewness $(<2)$ and kurtosis $(<2)$ analyses of $\mathrm{Cd}$ and $\mathrm{Cr}$ concentrations in the river, treated, and tap water indicated normal 
distribution of the data, except in the household $(\mathrm{HH})$ filtered water data of $\mathrm{Cr}$ because the kurtosis value was $>4$.

Table 1. Mean Cd and Cr concentrations (mg/L) in drinking water at Langat River Basin, Malaysia (2015).

\begin{tabular}{ccccccccc}
\hline Sample & Metal & Range & Mean & Skewness & Kurtosis & MOH $^{\mathbf{1}}$ & USEPA $^{2}$ & EC $^{3}$ \\
\hline River & $\mathrm{Cd}(\mathrm{mg} / \mathrm{L})$ & $3.9 \times 10^{-4}-34.3 \times 10^{-4}$ & $12.2 \times 10^{-4} \pm 3.8 \times 10^{-4}$ & 1.03 & 0.13 & 0.003 & 0.00072 & 0.0022 \\
water & $\mathrm{Cr}(\mathrm{mg} / \mathrm{L})$ & $1.2 \times 10^{-4}-12.2 \times 10^{-4}$ & $4.7 \times 10^{-4} \pm 2.7 \times 10^{-4}$ & 1.33 & 1.90 & 0.05 & 0.011 & - \\
\hline Treated & & $1.2 \times 10^{-4}-9.9 \times 10^{-4}$ & $4.2 \times 10^{-4} \pm 3.1 \times 10^{-4}$ & 0.91 & -0.84 & 0.003 & $0.005^{4}$ & $0.003^{5}$ \\
water & $0.2 \times 10^{-4}-5.3 \times 10^{-4}$ & $2.1 \times 10^{-4} \pm 1.4 \times 10^{-4}$ & 0.95 & 0.14 & 0.05 & $0.1^{4}$ & $0.05^{5}$ \\
\hline Tap & $1.3 \times 10^{-4}-7.7 \times 10^{-4}$ & $4.2 \times 10^{-4} \pm 1.9 \times 10^{-4}$ & 0.49 & -0.80 & 0.003 & $0.005^{4}$ & $0.003^{5}$ \\
water & $1.0 \times 10^{-4}-9.5 \times 10^{-4}$ & $3.7 \times 10^{-4} \pm 2.1 \times 10^{-4}$ & 1.08 & 0.76 & 0.05 & 0.14 & $0.05^{5}$ \\
\hline HH & & $0.3 \times 10^{-4}-7.4 \times 10^{-4}$ & $3.1 \times 10^{-3} \pm 2.1 \times 10^{-3}$ & 0.49 & -0.90 & 0.003 & $0.005^{4}$ & $0.003^{5}$ \\
filtration & & $0.5 \times 10^{-4}-6.6 \times 10^{-4}$ & $2 \times 10^{-3} \pm 1.5 \times 10^{-3}$ & 2.00 & 4.31 & 0.05 & $0.1^{4}$ & $0.05^{5}$ \\
\hline
\end{tabular}

Note: ${ }^{1}$ Raw Water Quality Standard proposed by Ministry of Health Malaysia [74]; ${ }^{2}$ Criteria Continuous Concentration by United States Environmental Protection Agency [75]; ${ }^{3}$ Annual Average proposed by European Commission [76]; ${ }^{4}$ Regulated Drinking Water proposed by United States Environmental Protection Agency [77]; ${ }^{5}$ Guidelines for Drinking Water Quality proposed by World Health Organization [78]. ${ }^{6} \mathrm{HH}$ filtration refers to household's filtered water sample.

The maximum high concentration of $\mathrm{Cd}\left(34.3 \times 10^{-4} \mathrm{mg} / \mathrm{L}\right)$ in the Langat River might be due to the natural weathering of $\mathrm{Cd}$ from the zinc ores such as sphalerite ( $\mathrm{ZnS})$ or $\mathrm{Cd}$ minerals such as greenockite [79] in the Titiwangsa Granite Hill Range of the basin. The point sources of pollution from sewage treatment plant effluent also attributed high concentration of Cd. Similarly, waste dumping in the river, runoff from landfills, and industrial waste from the metal finishing process at Bukit Tempoi might have contributed to high Cd concentration in the Langat River. Accordingly, the maximum concentration of $\mathrm{Cr}\left(12.2 \times 10^{-4} \mathrm{mg} / \mathrm{L}\right)$ in the Langat River indicated pollution in the mid-stream of the river basin from metal finishing industries such as electroplating, etching, and preparation of metal components for various industries [6,80]. Similarly, corrosion inhibitors, pigments from industrial effluents, and lithogenic sources contributed to high concentrations of $\mathrm{Cr}$ in Langat River [10,81].

The one-way ANOVA of $\mathrm{Cd}\left(F=27.6 ; p=5.99 \times 10^{-14}\right)$ and $\mathrm{Cr}\left(F=13.1 ; p=1.56 \times 10^{-7}\right)$ in the Langat River Basin found significant differences at 0.05 confidence level among the four stages of drinking water supply chain (Table A1). The least significant difference (LSD) of the post hoc test also found significant mean differences of $\mathrm{Cd}$ concentration between river water and water treatment plants $\left(p=4.3 \times 10^{-9}\right)$, tap water $\left(p=3.5 \times 10^{-11}\right)$, and HH filtered water $\left(p=6 \times 10^{-13}\right)$ at $95 \%$ confidence interval (Figure 2). Similarly, significant differences were found in the concentration of Cr between river water and treatment plants $\left(p=9 \times 10^{-5}\right)$ and HH filtered water $\left(p=2 \times 10^{-6}\right)$ (Figure 3). Moreover, significant differences of $\mathrm{Cd}$ and $\mathrm{Cr}$ concentrations were also observed among the river water sampling points, as well as among the WTPs, tap water, and HH filtered water at a 95\% confidence level (Figure 4).

The mean dissolved concentration of $\mathrm{Cd}$ in the supply water of the basin was estimated as being $0.42 \times 10^{-3} \pm 0.19 \times 10^{-3} \mathrm{mg} / \mathrm{L}$ (Table 2 ) and was within the drinking water quality standard proposed by $\mathrm{MOH}$ and $\mathrm{WHO}(0.003 \mathrm{mg} / \mathrm{L})$. The highest concentrations of dissolved $\mathrm{Cd}$ was observed at the location Hentian Kajang II $\left(0.75 \times 10^{-3} \pm 0.02 \times 10^{-3} \mathrm{mg} / \mathrm{L}\right)$, followed by the location Universiti Kebangsaan Malaysia (UKM) III $0.73 \times 10^{-3} \pm 0.04 \times 10^{-3} \mathrm{mg} / \mathrm{L}$. The high concentration of dissolved Cd in the water distribution system might have been due to corrosion in galvanized (i.e., zinc-coated) pipelines or cadmium-containing solders in fittings and taps. Hence, the leaching of $\mathrm{Cd}$ from galvanized pipes occurred because of the presence of $\mathrm{Cd}$ and lead $(\mathrm{Pb})$ impurities in the zinc [82] of galvanized pipe along with the residence time of low $\mathrm{pH}$ water from the use of lime in water treatment [17]. 


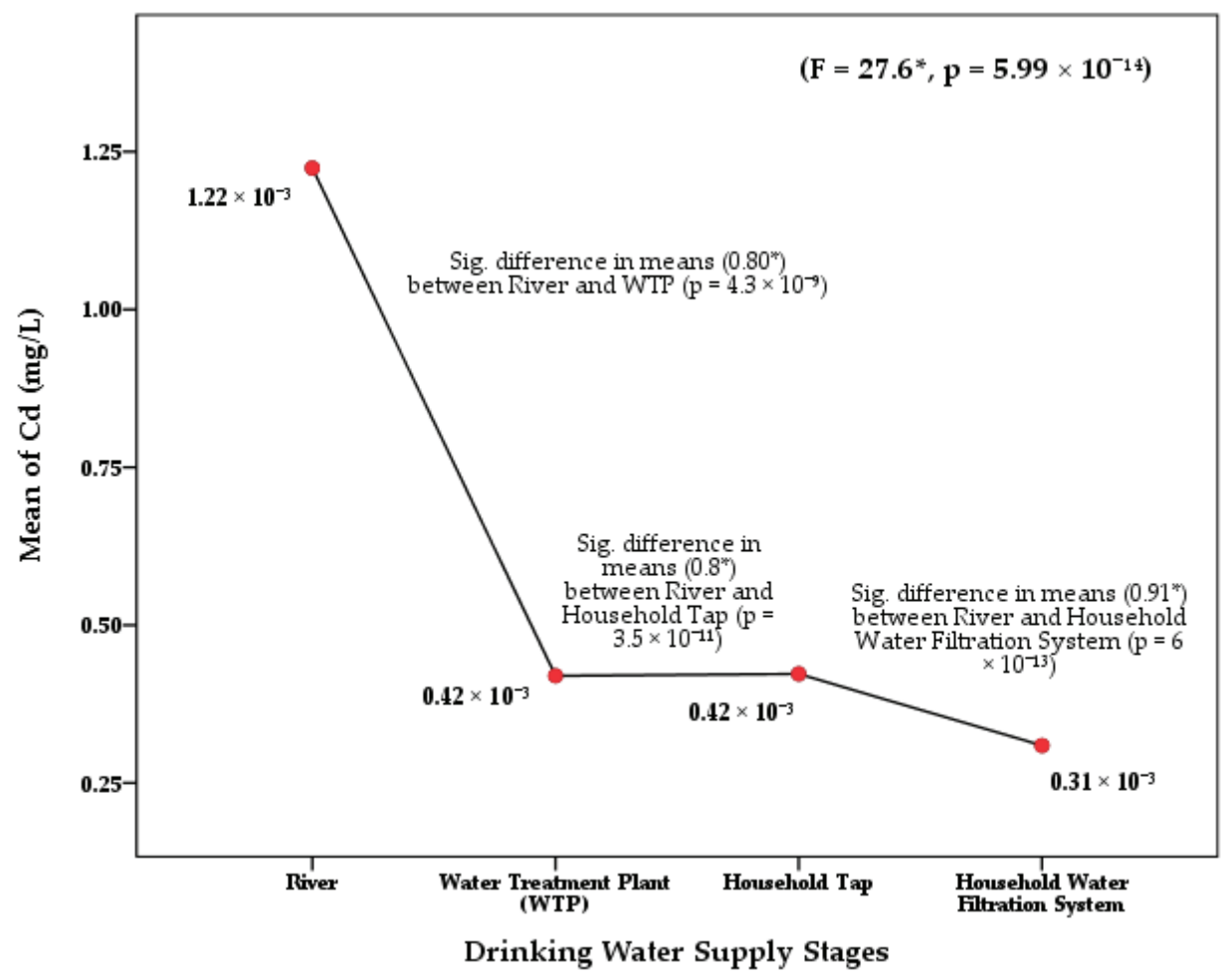

Figure 2. Difference in means of Cd concentrations in the drinking water supply chain at the Langat River Basin, Malaysia. Note: * significant at a 95\% confidence level (Table A2).

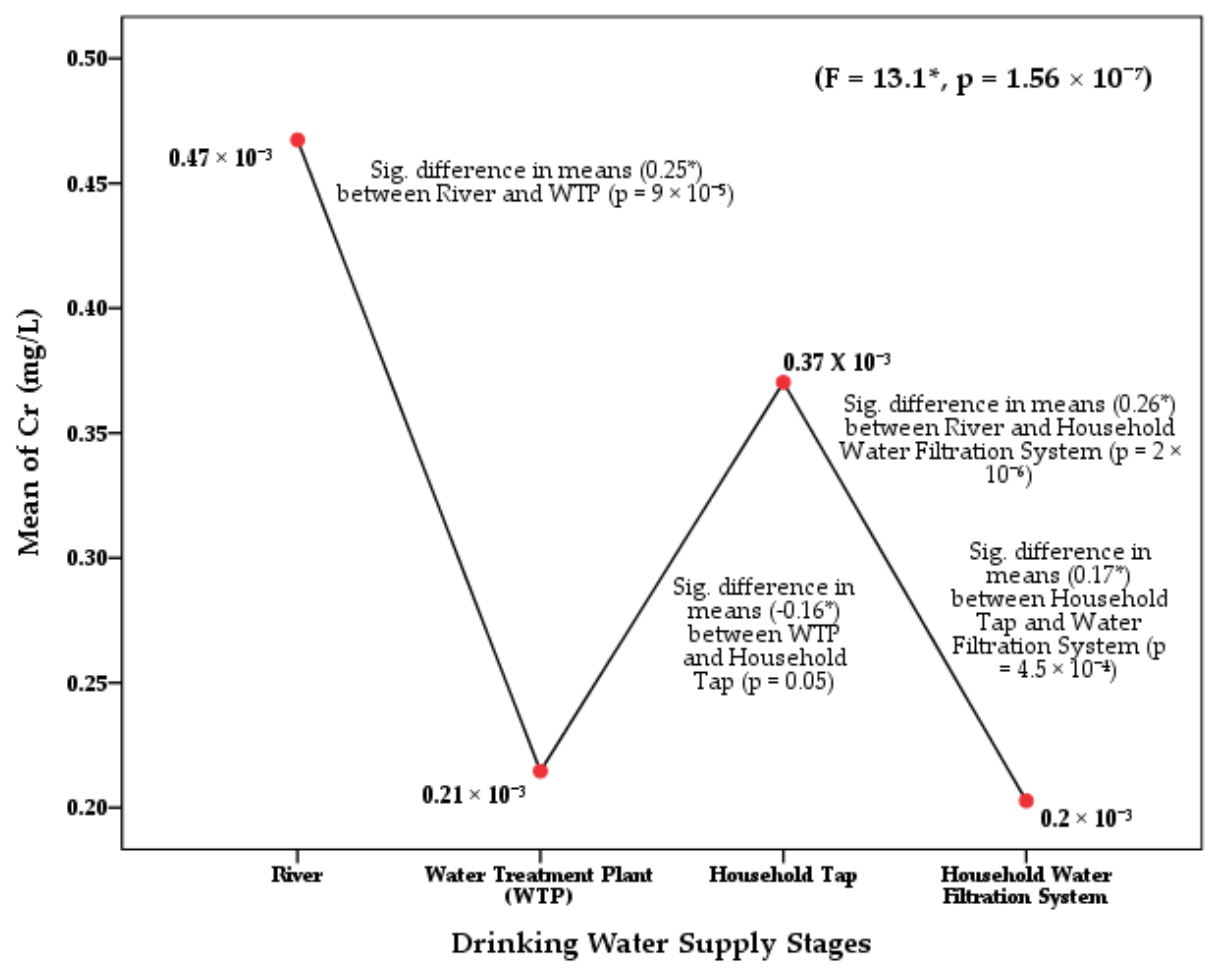

Figure 3. Difference in means of $\mathrm{Cr}$ concentrations in the drinking water supply chain at the Langat River Basin, Malaysia. Note: ${ }^{*}$ significant at a 95\% confidence level (Table A2). 

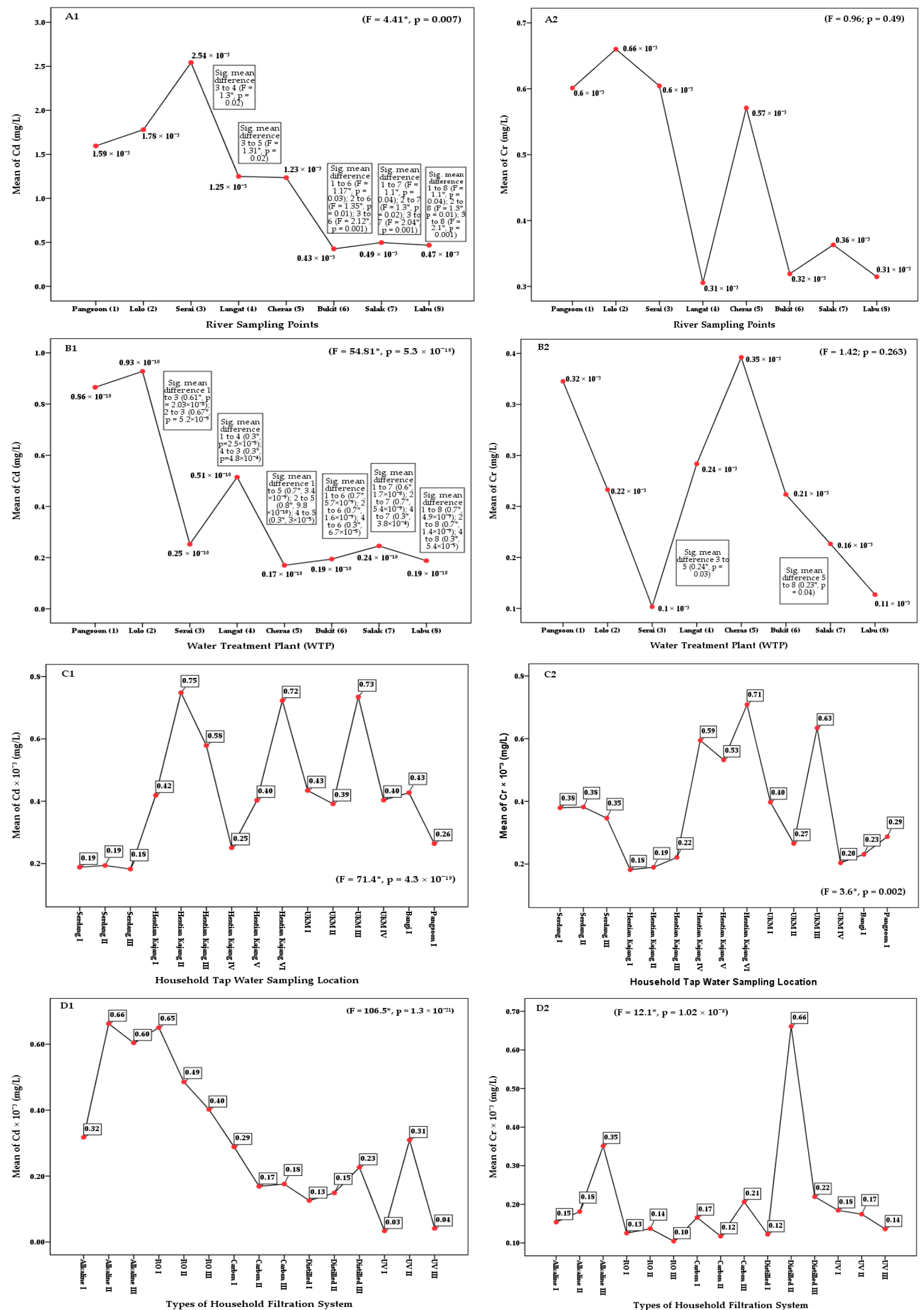

Figure 4. $\mathrm{Cd}$ and $\mathrm{Cr}$ concentration differences among the sampling points $((\mathbf{A 1}, \mathbf{A} 2)$ river, $(\mathbf{B 1}, \mathbf{B} 2)$ water treatment plant (WTP), (C1,C2) tap water, (D1,D2) household $(\mathrm{HH})$ filtered water). Note: * one-way ANOVA and least significant difference (LSD) post hoc test is significant at a $95 \%$ confidence level. 
Table 2. $\mathrm{Cd} \times 10^{-3}$ and $\mathrm{Cr} \times 10^{-3}$ concentrations (mg/L) in drinking water supply chain at Langat River Basin, Malaysia (2015).

\begin{tabular}{|c|c|c|c|c|c|c|c|c|c|}
\hline \multirow{2}{*}{$\begin{array}{l}\text { Water Sampling } \\
\text { Locations }\end{array}$} & \multicolumn{2}{|c|}{ River } & \multicolumn{2}{|c|}{ Water Treatment Plant } & \multirow{2}{*}{ Filter (Household Locations) } & \multicolumn{2}{|c|}{ HH $^{1}$ Tap } & \multicolumn{2}{|c|}{$\mathrm{HH}^{2}$ Filtration } \\
\hline & $\mathrm{Cd}(\mathrm{mg} / \mathrm{L})$ & $\mathrm{Cr}(\mathrm{mg} / \mathrm{L})$ & $\mathrm{Cd}(\mathrm{mg} / \mathrm{L})$ & $\mathrm{Cr}(\mathrm{mg} / \mathrm{L})$ & & $\mathrm{Cd}(\mathrm{mg} / \mathrm{L})$ & $\mathrm{Cr}(\mathrm{mg} / \mathrm{L})$ & $\mathrm{Cd}(\mathrm{mg} / \mathrm{L})$ & $\mathrm{Cr}(\mathrm{mg} / \mathrm{L})$ \\
\hline Pangsoon & $1.60 \pm 0.66$ & $0.60 \pm 0.56$ & $0.87 \pm 0.12$ & $0.32 \pm 0.21$ & Alkaline I (Serdang I) & $0.19 \pm 0.06$ & $0.38 \pm 0.12$ & $0.32 \pm 0.002$ & $0.15 \pm 0.09$ \\
\hline Lolo & $1.78 \pm 1.43$ & $0.66 \pm 0.36$ & $0.93 \pm 0.06$ & $0.22 \pm 0.2$ & Alkaline II (Serdang II) & $0.19 \pm 0.03$ & $0.38 \pm 0.12$ & $0.66 \pm 0.08$ & $0.18 \pm 0.09$ \\
\hline Serai & $2.54 \pm 0.02$ & $0.60 \pm 0.04$ & $0.25 \pm 0.09$ & $0.1 \pm 0.02$ & Alkaline III (Serdang III) & $0.18 \pm 0.02$ & $0.35 \pm 0.12$ & $0.6 \pm 0.02$ & $0.35 \pm 0.13$ \\
\hline Langat & $1.25 \pm 0.09$ & $0.31 \pm 0.14$ & $0.51 \pm 0.1$ & $0.24 \pm 0.16$ & $\mathrm{RO}^{3}$ I (Hentian Kajang I) & $0.42 \pm 0.01$ & $0.18 \pm 0.03$ & $0.65 \pm 0.01$ & $0.13 \pm 0.04$ \\
\hline Cheras & $1.23 \pm 0.73$ & $0.57 \pm 0.32$ & $0.17 \pm 0.05$ & $0.35 \pm 0.13$ & RO ${ }^{3}$ II (Hentian Kajang II) & $0.75 \pm 0.02$ & $0.19 \pm 0.01$ & $0.49 \pm 0.03$ & $0.14 \pm 0.09$ \\
\hline Bukit & $0.43 \pm 0.03$ & $0.32 \pm 0.12$ & $0.19 \pm 0.02$ & $0.21 \pm 0.07$ & RO ${ }^{3}$ III (Hentian Kajang III) & $0.58 \pm 0.08$ & $0.22 \pm 0.08$ & $0.4 \pm 0.01$ & $0.1 \pm 0.02$ \\
\hline Salak & $0.50 \pm 0.04$ & $0.36 \pm 0.02$ & $0.25 \pm 0.05$ & $0.16 \pm 0.01$ & Carbon I (Hentian Kajang IV) & $0.25 \pm 0.04$ & $0.59 \pm 0.2$ & $0.29 \pm 0.04$ & $0.17 \pm 0.09$ \\
\hline Labu & $0.47 \pm 0.04$ & $0.31 \pm 0.12$ & $0.19 \pm 0.05$ & $0.11 \pm 0.03$ & Carbon II (Hentian Kajang V) & $0.40 \pm 0.03$ & $0.53 \pm 0.08$ & $0.17 \pm 0.08$ & $0.12 \pm 0.03$ \\
\hline \multirow[t]{8}{*}{ Mean } & $1.22 \pm 0.38$ & $0.47 \pm 0.21$ & $0.42 \pm 0.31$ & $0.21 \pm 0.14$ & Carbon III (UKM II) & $0.39 \pm 0.03$ & $0.27 \pm 0.25$ & $0.18 \pm 0.01$ & $0.21 \pm 0.01$ \\
\hline & & & & & Distilled I (UKM III) & $0.73 \pm 0.04$ & $0.63 \pm 0.02$ & $0.13 \pm 0.01$ & $0.12 \pm 0.01$ \\
\hline & & & & & Distilled II (Hentian Kajang VI) & $0.72 \pm 0.07$ & $0.71 \pm 0.41$ & $0.15 \pm 0.02$ & $0.66 \pm 0.003$ \\
\hline & & & & & Distilled III (UKM I) & $0.43 \pm 0.03$ & $0.4 \pm 0.14$ & $0.23 \pm 0.04$ & $0.22 \pm 0.07$ \\
\hline & & & & & UV I (Bangi I) & $0.43 \pm 0.01$ & $0.23 \pm 0.150$ & $0.03 \pm 0.01$ & $0.18 \pm 0.01$ \\
\hline & & & & & UV II (UKM IV) & $0.4 \pm 0.03$ & $0.2 \pm 0.04$ & $0.31 \pm 0.02$ & $0.17 \pm 0.12$ \\
\hline & & & & & UV III (Hentian Kajang VII) & $0.26 \pm 0.03$ & $0.29 \pm 0.004$ & $0.04 \pm 0.01$ & $0.14 \pm 0.04$ \\
\hline & & & & & Mean & $0.42 \pm 0.19$ & $0.37 \pm 0.21$ & $0.31 \pm 0.21$ & $0.2 \pm 0.15$ \\
\hline
\end{tabular}

Note: ${ }^{1} \mathrm{HH}$ refers to household. ${ }^{2} \mathrm{HH}$ filtration refers to filtered water at household. ${ }^{3}$ RO refers to reverse osmosis (household water filtration system). 
Similarly, the mean concentration of dissolved $\mathrm{Cr}$ in the supply water of the basin $\left(0.37 \times 10^{-3} \pm\right.$ $0.21 \times 10^{-3} \mathrm{mg} / \mathrm{L}$ ) was lower than the maximum limit of drinking water quality standard proposed by the $\mathrm{MOH}, \mathrm{WHO}$, and $\mathrm{EC}(0.5 \mathrm{mg} / \mathrm{L})$. The highest concentrations of dissolved $\mathrm{Cr}$ were recorded at Hentian Kajang VI $\left(0.71 \times 10^{-3} \pm 0.41 \times 10^{-3} \mathrm{mg} / \mathrm{L}\right)$ and Universiti Kebangsaan Malaysia (UKM) III $\left(0.63 \times 10^{-3} \pm 0.02 \times 10^{-3} \mathrm{mg} / \mathrm{L}\right)$. The high concentration of dissolved $\mathrm{Cr}$ at Hentian Kajang and UKM might have been due to corrosion of $\mathrm{Cr}$ in the steel pipes (steel alloy and chromium) of the drinking water distribution system [83-86]. Moreover, the stagnant water period in the water distribution system was also an important factor to increase the concentration of dissolved $\mathrm{Cr}$ in supply water [87].

Accordingly, the high concentration of Cd at Alkaline II $\left(0.66 \times 10^{-3} \pm 0.08 \times 10^{-3} \mathrm{mg} / \mathrm{L}\right)$ and Reverse Osmosis (RO) I filtered water $\left(0.65 \times 10^{-3} \pm 0.01 \times 10^{-3} \mathrm{mg} / \mathrm{L}\right)$ might have been due to microorganism growth on the cartridge. Irregular cleaning activities can lead to inorganic ion deposition on the cartridge [88-92]. Leaching of ions from the cartridge contributed to high concentrations of trace metals (e.g., Cd) in drinking water. However, the mean concentration of dissolved $\mathrm{Cd}\left(0.31 \times 10^{-3}\right.$ $\pm 0.21 \times 10^{-3} \mathrm{mg} / \mathrm{L}$ ) in $\mathrm{HH}$ filtration water at the basin was lower than the drinking water quality standards of $0.003 \mathrm{mg} / \mathrm{L}$ proposed by the $\mathrm{MOH}$ and $\mathrm{WHO}$ and $0.5 \mathrm{mg} / \mathrm{L}$ proposed by the USEPA and EC. However, the RO vendor machine at Johor, Malaysia, found a lower concentration of $\mathrm{Cd}(0.08 \times$ $\left.10^{-3} \pm 0.03 \times 10^{-3} \mathrm{mg} / \mathrm{L}\right)$ and $\mathrm{Cr}\left(0.39 \times 10^{-3} \pm 0.09 \times 10^{-3} \mathrm{mg} / \mathrm{L}\right)$ in the filtered water [93].

The high dissolved concentrations of $\mathrm{Cr}$ in the Distilled II $\left(0.66 \times 10^{-3} \pm 0.003 \times 10^{-3} \mathrm{mg} / \mathrm{L}\right)$ and Alkaline III $\left(0.35 \times 10^{-3} \pm 0.13 \times 10^{-3} \mathrm{mg} / \mathrm{L}\right)$ filtered waters might have been due to corrosion of galvanized iron pipes linked to steel pipes at the end of the reticulation system along with stagnant water time within the filter. Moreover, rust inside distilled filters and a lack of cleaning activities also contributed to high concentrations of $\mathrm{Cr}$ in the drinking water. However, the mean concentration of dissolved $\mathrm{Cr}\left(0.2 \times 10^{-3} \pm 0.15 \times 10^{-3} \mathrm{mg} / \mathrm{L}\right)$ in the $\mathrm{HH}$ filtered water at the basin was below the maximum limit of the drinking water quality standard of $\mathrm{Cr}(0.50 \mathrm{mg} / \mathrm{L})$ proposed by the $\mathrm{MOH}, \mathrm{WHO}$, and EC.

\subsection{Prediction Model of Metal Concentrations in Drinking Water Supply Chain}

The time series data of $\mathrm{Cd}$ and $\mathrm{Cr}$ concentrations in Langat River complied with the time series data analysis at $99 \%$ confidence interval. The compliance of time series data analysis was based on the significant augmented Dickey-Fuller (ADF) unit root test for $\mathrm{Cd}$ and $\mathrm{Cr}$ at 0.05 level (Table A3). The ADF unit root test of $\mathrm{Cr}$ with constant was not significant $(p=0.65)$ at the 0.05 level; however, the ADF unit root test of $\mathrm{Cr}$ with constant (i.e., considering $\mathrm{Cr}$ trend) was significant $\left(p=7.17 \times 10^{-2}\right)$ at the 0.05 level. Similarly, the autocorrelation (ACF) plots based on the differences in $\mathrm{Cd}$ and $\mathrm{Cr}$ concentrations showed significant autocorrelation only at Lag 1, although the ADF unit root test of $\mathrm{Cd}$ and $\mathrm{Cr}$ data remained static at a 95\% confidence level. Similarly, the partial autocorrelation (PACF) plots based on the differences $\mathrm{Cd}$ and $\mathrm{Cr}$ concentrations with a $95 \%$ confidence band showed that the autocorrelation was only significant at Lag 1 and Lag 2 (Figures A1 and A2). Therefore, this study used a monthly (2005-2020) auto regression model to estimate the Lag effects on Cd (Table A4) and $\mathrm{Cr}$ (Table A5) concentrations in the drinking water supply chain of the Langat River Basin. The impact of the prior three months (i.e., identified Lags in Table A6) had significant influence on the Cd concentration trend in Langat River after 2016. The predicted Cd concentration considering the influences of environmental parameters (i.e., water flow, rainfall, and temperature) was also similar to the determined Cd concentration in 2015. Similarly, the impact of prior month (i.e. identified Lag in Table A7) had significant influence on the Cr concentration trend in Langat River after 2016.

Lag 1 to Lag 7 effects in the auto-regressive Cd model (Table A4) suggested that the consecutive prior seven months had a significant impact on the $\mathrm{Cd}$ concentration of the current month in Langat River, where $\operatorname{Lag} 7(t=2.32 ; p=0.02)$ was significant at the 0.05 level. In addition, the sixth-order auto-generative coefficient weight $0.21(t=2.23 ; p=0.03)$ was significant at the 0.05 level to have an autocorrelation-free $\mathrm{Cd}$ concentration forecast model, because Lag 7 in both ACF and PACF crossed the $95 \%$ interval line, indicating the existence of autocorrelation. Therefore, the auto-regressive 
moving average of Cd concentration based on the data from January 2005 to August 2015 forecasted $9.7 \times 10^{-4} \mathrm{mg} / \mathrm{L}$ in January 2020 (Figure 5) and a mean Cd concentration of $9.75 \times 10^{-4} \pm 1.33 \times 10^{-4}$ $\mathrm{mg} / \mathrm{L}$ during 2005-2020 (Figure 6). Moreover, the predicted Cd concentration $\left(9.7 \times 10^{-4} \mathrm{mg} / \mathrm{L}\right)$ in 2020 was a little bit higher than the mean Cd concentration $\left(9.69 \times 10^{-4} \pm 1.57 \times 10^{-4}\right) \mathrm{mg} / \mathrm{L}$ in Langat River during 2005-2015 (Figure 6). The predicted Cd concentration $\left(9.7 \times 10^{-4} \mathrm{mg} / \mathrm{L}\right)$ at January 2020 in Langat river was significant $\left(R^{2}=0.08 ; F=2.4 ; p=0.03\right)$ at a 95\% confidence interval. Similarly, the forecast of $\mathrm{Cd}$ concentration $\left(9.8 \times 10^{-4} \mathrm{mg} / \mathrm{L}\right)$ in August 2015 was similar to the real concentration of $\mathrm{Cr}$ $9.7 \times 10^{-4} \mathrm{mg} / \mathrm{L}$ in August 2015 in Langat River considering the influence of significant environmental parameters (Figure A3). Moreover, the concentration of Cd in the Langat River was influenced by the Cd concentration of the prior 3 months $(t=-2.37 ; p=0.02$; Table A6) and the model was significant $\left(R^{2}=0.05 ; F=9.4 ; p=2.2 \times 10^{-8} ;\right.$ Figure A3) at the 0.05 level.

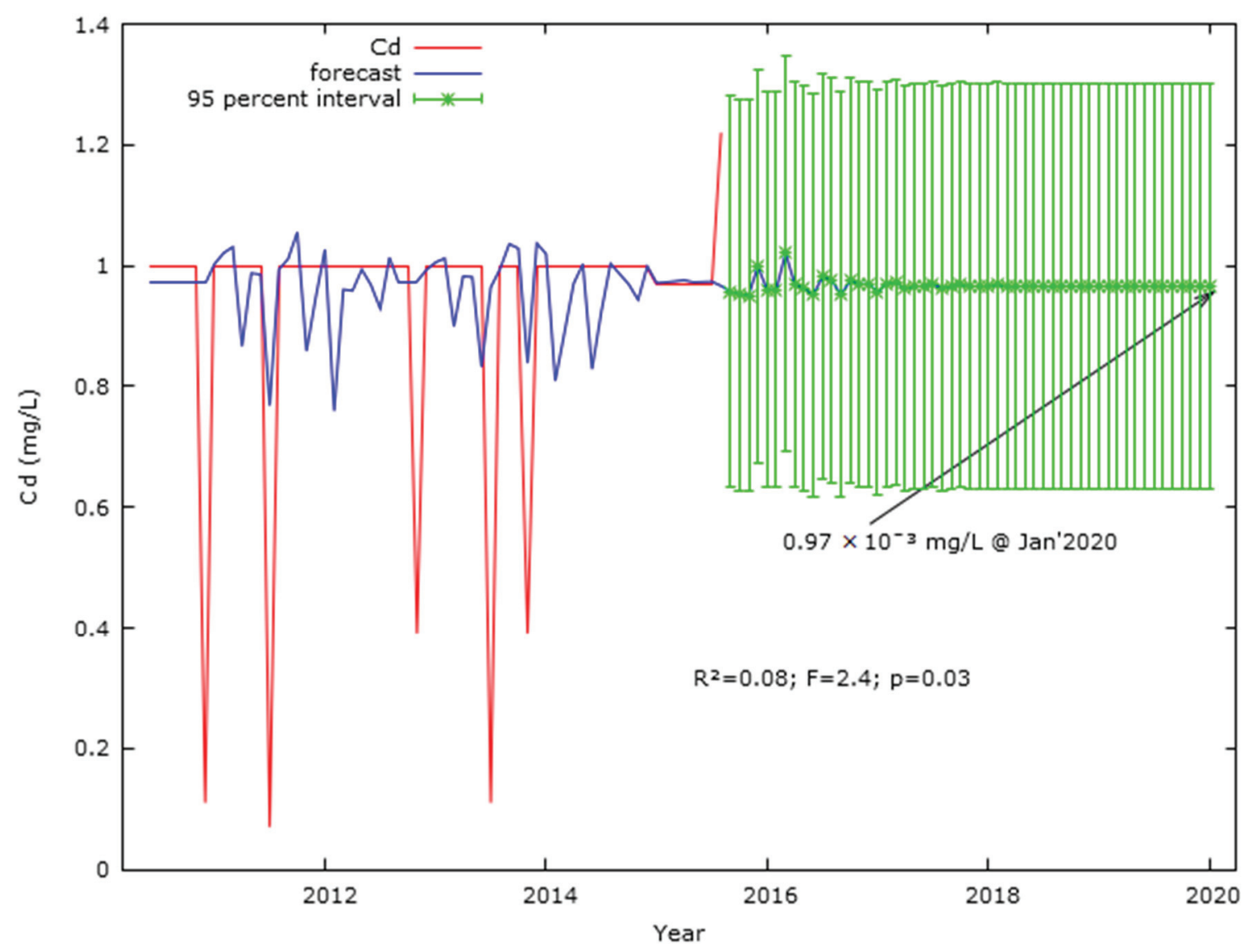

Figure 5. Forecast of $\mathrm{Cd}(\mathrm{mg} / \mathrm{L})$ concentration in Langat River on the basis of auto-generative moving average from January 2005 to January 2020. Note: Y-axis refers to Cd concentration in $\mathrm{mg} / \mathrm{L}$ and explains the predicted $\mathrm{Cd}$ concentration along with the range of percentile to validate the predicted trend. 


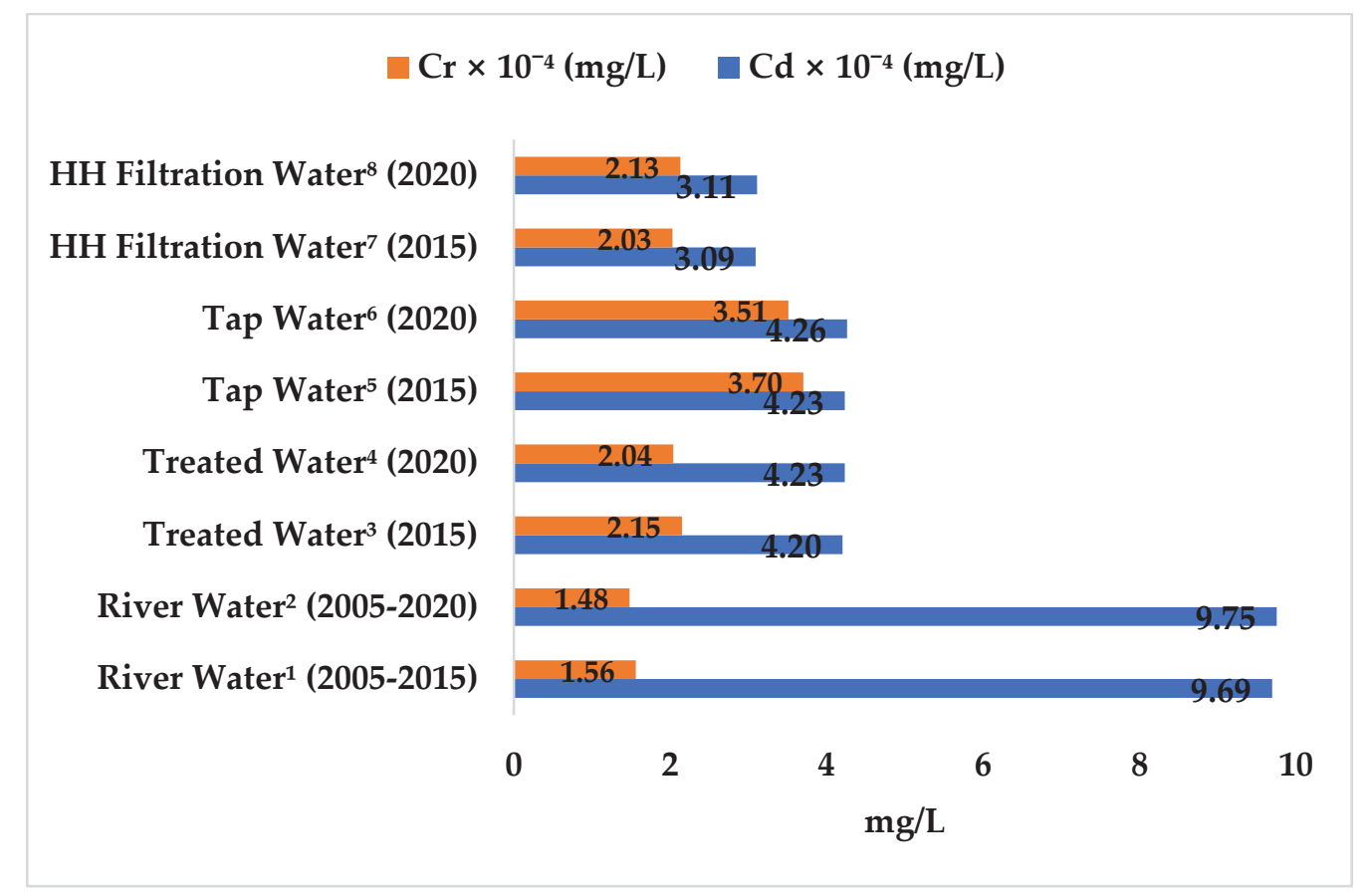

Figure 6. Forecast of $\mathrm{Cr}(\mathrm{mg} / \mathrm{L})$ concentration in Langat River on the basis of auto-generative moving average from January 2005 to January 2020. Note: $\mathrm{X}$-axis refers to $\mathrm{Cd}$ and $\mathrm{Cr}$ concentrations in $\mathrm{mg} / \mathrm{L}$. Percentage change of $\mathrm{Cd}(0.63 \%)$ and $\mathrm{Cr}(-5.04 \%)$ concentration was based on the difference of concentration between 2005-2015 and 2020. ${ }^{1}$ Determined concentrations were based on the time series data (2005-2014) and laboratory results (2015) of this study. ${ }^{2}$ Predicted concentrations were obtained from the auto-generative moving average forecast model. ${ }^{3,5,7}$ Laboratory results of this study. ${ }^{4,6,8}$ Predicted concentrations in treated, tap, and household filter water were calculated on the basis of the percentage change of metal concentrations in the river. HH refers to household.

The significant $\operatorname{Lag} 1(t=3.1 ; p=0.002)$ and $\operatorname{Lag} 2\left(t=9.63 ; p=1.25 \times 10^{-16}\right)$ effects at the 0.05 level in the auto-regressive $\mathrm{Cr}$ model (Table A5) suggested that the impact of the prior 2 months had significant effects on the $\mathrm{Cr}$ concentration in Langat River. Similarly, the second order auto-generative coefficient weight of $-0.47\left(t=-5.998 ; p=2.13 \times 10^{-8}\right.$; Table A5) was significant at the 0.05 level to have an autocorrelation-free $\mathrm{Cr}$ concentration forecast model; the ACF and PACF correlogram of the initial few Lags crossed the 95\% interval line, indicating the existence of autocorrelations. Therefore, the auto-generative moving average of $\mathrm{Cr}$ concentration based on the data from January 2005 to August 2015 forecasted $1.32 \times 10^{-3} \mathrm{mg} / \mathrm{L}$ in January 2020 (Figure 7) as well as a mean $\mathrm{Cr}$ concentration of $1.48 \times$ $10^{-3} \pm 8.84 \times 10^{-4} \mathrm{mg} / \mathrm{L}$ during $2005-2020$. Moreover, the predicted $\mathrm{Cr}$ concentration $\left(1.32 \times 10^{-3} \mathrm{mg} / \mathrm{L}\right)$ in January 2020 was lower than the mean Cr concentration $\left(1.56 \times 10^{-3} \pm 1.05 \times 10^{-3} \mathrm{mg} / \mathrm{L}\right)$ in Langat River during 2005-2015. However, the predicted Cr concentration $\left(1.32 \times 10^{-3} \mathrm{mg} / \mathrm{L}\right)$ at January 2020 in Langat river was significant $\left(R^{2}=0.44 ; F=130.28 ; p=6.7 \times 10^{-31}\right.$; Figure 7$)$ at a $95 \%$ confidence level. Similarly, considering the control variables such as water flow, rainfall, and temperature, the $\mathrm{Cr}$ concentration in Langat River at 2015 was significantly influenced by the concentration of prior two months (Lag 2, $t=3.6744 ; p=0.0004$; Table A7). The model was significant $\left(R^{2}=0.36 ; F=5.37 ; p=5.1\right.$ $\times 10^{-4}$; Figure A4) at the 0.05 level and the forecasted and real concentrations of $\mathrm{Cr}$ in the Langat River were almost similar. 


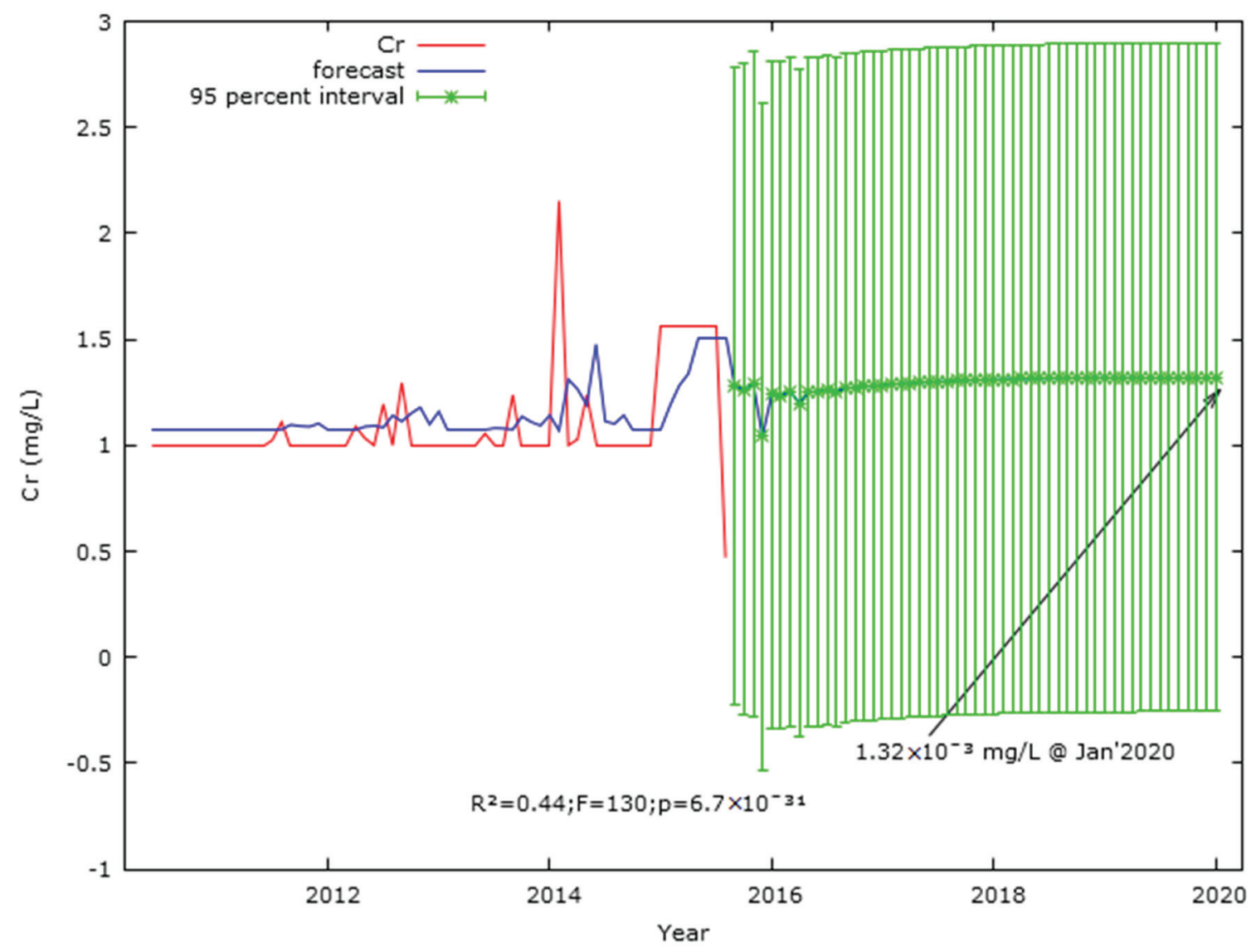

Figure 7. Forecast of $\mathrm{Cr}(\mathrm{mg} / \mathrm{L})$ concentration in Langat River on the basis of auto generative moving average from January 2005 to January 2020. Note: $Y$-axis refers to $\mathrm{Cr}$ concentration in $\mathrm{mg} / \mathrm{L}$ and explains the predicted $\mathrm{Cr}$ concentration along with the range of percentile to validate the predicted trend.

\subsection{Prediction Model of Metal Concentrations in Drinking Water Supply Chain}

Cd concentration in the drinking water supply chain at Langat Basin both in 2015 and 2020 were within the maximum limit of the drinking water quality standard of the $\mathrm{MOH}(0.003 \mathrm{mg} / \mathrm{L}), \mathrm{WHO}(0.003$ $\mathrm{mg} / \mathrm{L})$, and USEPA $(0.0022 \mathrm{mg} / \mathrm{L})$. Cadmium concentration $\left(3.11 \times 10^{-4} \mathrm{mg} / \mathrm{L}\right)$ in HH filtration water in 2020 (Figure 6) was also well below the maximum tolerable daily intake of $\mathrm{Cd}$ through drinking water $\left(8.3 \times 10^{-4} \mathrm{mg} / \mathrm{L}\right)$ [37]. Therefore, $\mathrm{Cd}$ ingestion through HH filtration water in the Langat Basin posed no health risk because the HQ $\left(2.67 \times 10^{-2} \pm 1.23 \times 10^{-2} \mathrm{mg} / \mathrm{L}\right.$ and $2.69 \times 10^{-2} \mathrm{mg} / \mathrm{L}$ in 2015 and 2020, respectively; Figure 8 ) were significantly within the safe limit (i.e., $\mathrm{HQ}<1$ at $95 \%$ confidence level).

Accordingly, $\mathrm{Cr}$ concentration in the drinking water supply chain in Langat Basin in 2015 and 2020 were within the safe limit of the drinking water quality standard of the $\mathrm{MOH}(0.05 \mathrm{mg} / \mathrm{L})$, WHO $(0.05 \mathrm{mg} / \mathrm{L})$, and USEPA $(0.011 \mathrm{mg} / \mathrm{L})$. The concentration of $\mathrm{Cr}\left(2.13 \times 10^{-4} \mathrm{mg} / \mathrm{L}\right)$ in $\mathrm{HH}$ filtration water in 2020 were predicted in this study (Figure 6), however, the maximum tolerable daily intake of $\mathrm{Cr}$ through drinking water for humans has yet to be fixed [94]. Hence, $\mathrm{Cr}$ ingestion through $\mathrm{HH}$ filtration water in Langat Basin showed no potential non-carcinogenic human health risk $\left(2.13 \times 10^{-3}\right.$ $\pm 1.55 \times 10^{-3} \mathrm{mg} / \mathrm{L}$ and $2.24 \times 10^{-3} \mathrm{mg} / \mathrm{L}$ in 2015 and 2020, respectively; Figure 8) because the values were within the safe limit (i.e., $\mathrm{HQ}<1$ ). Accordingly, the LCR values of $\mathrm{Cr}$ ingestion through $\mathrm{HH}$ filtration water $\left(1.28 \times 10^{-5} \pm 9.29 \times 10^{-6} \mathrm{mg} / \mathrm{L}\right.$ and $1.35 \times 10^{-5} \mathrm{mg} / \mathrm{L}$ in 2015 and 2020 , respectively; Figure 9) were within the safe limit because the LCR values were not greater than $\geq 1 \times 10^{-5} \mathrm{mg} / \mathrm{L}$ at a $95 \%$ confidence level. 


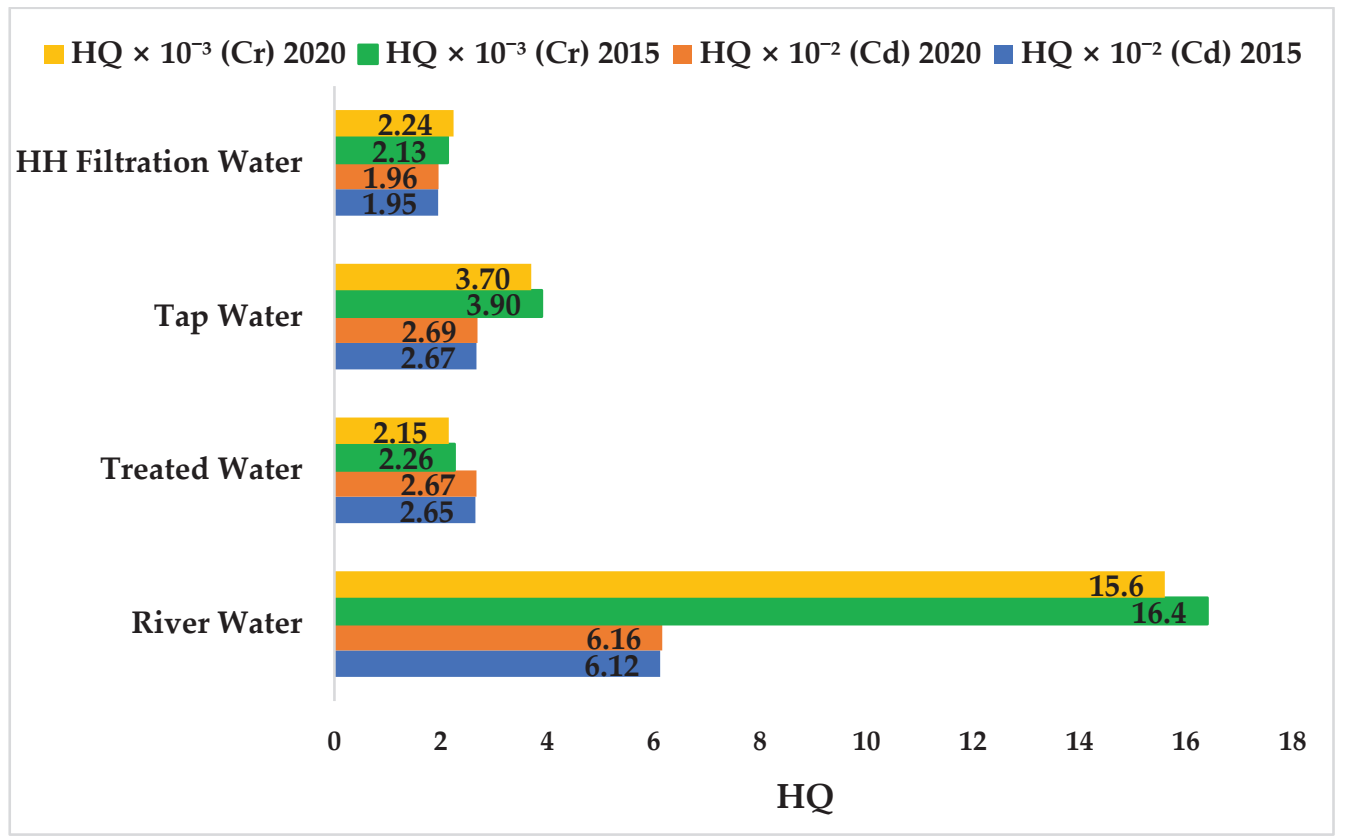

Figure 8. Non-carcinogenic risk values of $\mathrm{Cd}$ and $\mathrm{Cr}$ ingestion via drinking water in Langat River Basin, Malaysia. Note: $X$-axis refers to the non-carcinogenic value of hazard quotients $(\mathrm{HQ})$, and $\mathrm{HQ}$ value $<1$ is safe. River: HQ (Cd) 2015, $t=69.88, p=3.2 \times 10^{-103 *}$; HQ (Cd) 2020, $t=98.97, p=7.1 \times$ $10^{-159 *}$; HQ (Cr) 2015, $t=16.83, p=3.81 \times 10^{-34 *}$; HQ (Cr) 2020, $t=22.41, p=5.84 \times 10^{-54 *}$; treated water: $\mathrm{HQ}(\mathrm{Cd}) 2015, t=6.714, p=7.55 \times 10^{-7} * \mathrm{HQ}(\mathrm{Cr}) 2015, t=7.670, p=8.77 \times 10^{-8 *}$; tap: HQ (Cd) $2015, t=14.58, p=1.88 \times 10^{-18 *} ; \mathrm{HQ}(\mathrm{Cr}) 2015, t=11.64, p=5 \times 10^{-15} *$;H (household) filtration: HQ (Cd) 2015, $t=9.99, p=6.72 \times 10^{-13 *}$; HQ (Cr) 2015, $t=9.35, p=4.12 \times 10^{-12 *}{ }^{*}{ }^{*}$ significant at $95 \%$ level.

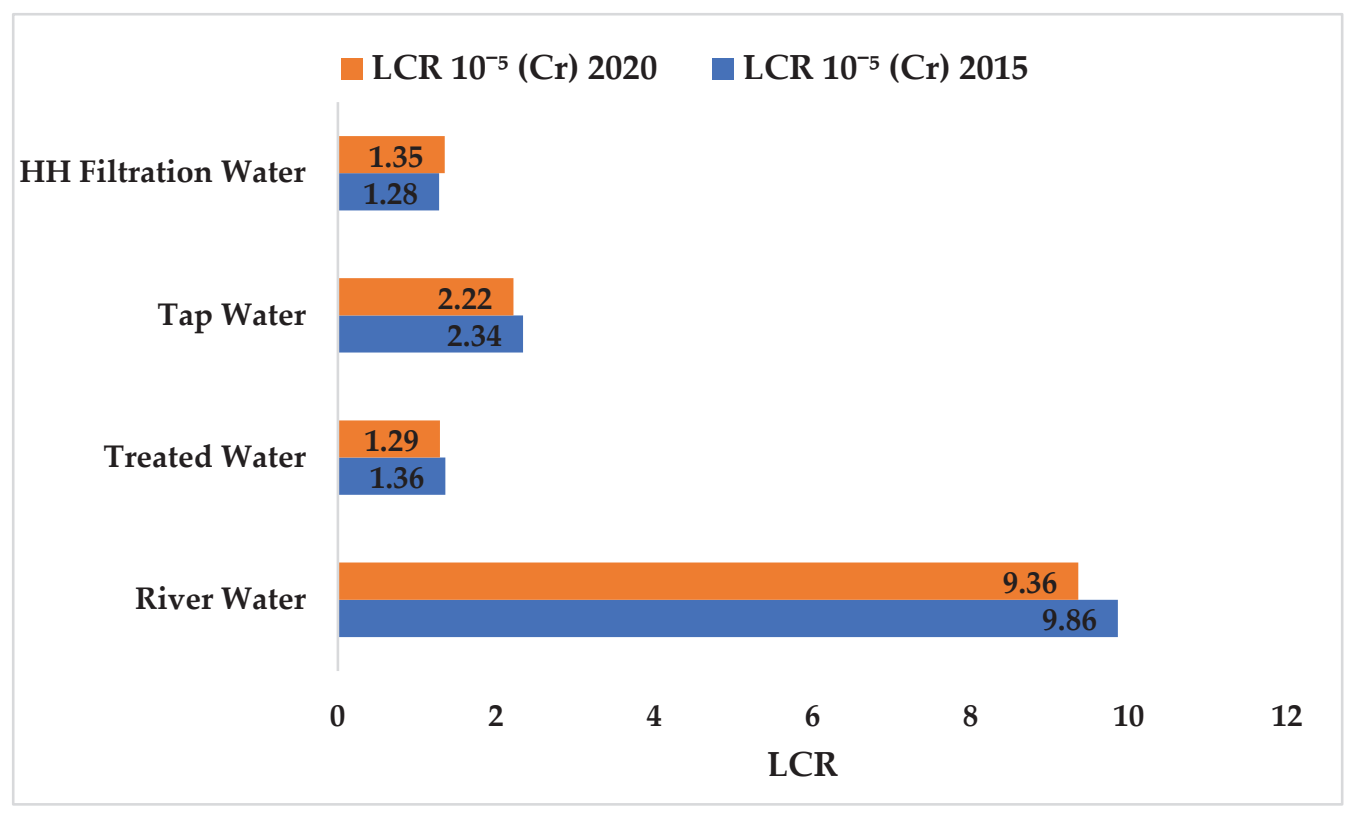

Figure 9. Carcinogenic risk values of $\mathrm{Cr}$ ingestion via drinking water in Malaysia. Note: $X$-axis refers to the carcinogenic lifetime cancer risk (LCR) value and LCR value $<10^{-5}$ is acceptable. River: $\mathrm{LCR}(\mathrm{Cr})$ $2015, t=16.83, p=3.81 \times 10^{-34 *} ; \mathrm{LCR}(\mathrm{Cr}) 2020, t=22.41, p=5.84 \times 10^{-54} *$; treated water: LCR $(\mathrm{Cr})$ $2015, t=7.670, p=8.77 \times 10^{-8} *$ t tap: LCR (Cr) 2015, $t=11.64, p=5 \times 10^{-15} *$ HH (household) filtration: LCR (Cr) 2015, $t=9.35, p=4.12 \times 10^{-12 *} ; *$ significant at 95\% level. LCR $=$ lifetime cancer risk. 
All eight water treatment plants (WTPs) in Langat Basin follow the conventional water treatment method. However, this conventional method was unable to fully remove trace metals from the treated water mainly because of frequent changes in turbidity in Langat River [3]. For instance, Frey [95] reported that a conventional coagulation method can remove $\mathrm{Cr}$ (III) from water; however, it cannot remove $\mathrm{Cr}$ (VI). Similarly, Brandhuber [96] reported that the total $\mathrm{Cr}$ removal varied between $40 \%$ and $100 \%$ with the conventional method because $\mathrm{Cr}(\mathrm{VI})$ cannot be removed by alum or ferric coagulation or by lime softening. Therefore, a two-layer water filtration system should be introduced in the Langat Basin because treated water contamination in the long pipeline was evident between WTPs and households; additionally, the conventional method was unable to fully remove metals from treated water. Hence, the reverse osmosis membrane technology can be appropriate to install in a kitchen tap of the household managed by the water billing agency because it can remove more than $90 \%$ of trace metals [97].

\section{Recommendations}

A two-layer water filtration system at the basin should be introduced to achieve the SDG target 6.1 of obtaining safe drinking water supply before 2030. Because the traditional coagulation method is unable to completely remove metals from treated water, and treated water contamination in the long pipeline was evident in between WTPs and households, a reverse osmosis filtration system with the capacity to remove more than $90 \%$ of metals could be installed at the kitchen tap of household. The installed reverse osmosis filtration system at household could be managed by the water billing agency and a less-expensive pond sand filtration at the treatment plants could be maintained. Furthermore, in managing the drinking water, the proactive leadership roles of local authority would be appropriate to enable the PENTA-HELIX (i.e. consists of five types of stakeholders such as public, private, academia, non-governmental organization and community) partnership model to bring public, business, academia, NGO (non-governmental organization), and community sectors into the same multi-stakeholder platform.

\section{Conclusions}

Cadmium and chromium concentrations in the drinking water supply chain at Langat Basin were within the drinking water quality standard of the Ministry of Health Malaysia and WHO. Moreover, $\mathrm{Cd}$ and $\mathrm{Cr}$ ingestion through household filtration water in the Langat Basin poses no health risk because the hazard quotients (HQ) of Cd and Cr were significantly within the safe limit in 2015 and 2020. Similarly, the LCR (lifetime cancer risk) value of $\mathrm{Cr}$ ingestion through household filtration water was within the safe limit in 2015 and 2020. However, high concentrations of these metals have been found in the household tap water mainly because of contamination in the water distribution pipeline. The age-old water distribution pipelines in between water treatment plants and households as well as the old water reticulation systems at the households in the Langat Basin might have attributed to $\mathrm{Cd}$ and $\mathrm{Cr}$ concentrations in the household tap water. Similarly, the irregular cleaning activities of the household water filtration systems might have also attributed to the $\mathrm{Cd}$ and $\mathrm{Cr}$ concentrations in the drinking water.

Author Contributions: Conceptualization, M.F.A. and M.B.M.; methodology, M.F.A. and M.B.M.; validation, M.F.A. and M.B.M.; formal analysis, M.F.A.; investigation, M.F.A.; resources, M.F.A. and M.B.M.; data curation, M.F.A.; writing_-original draft preparation, M.F.A.; writing—review and editing, M.B.M.; visualization, M.B.M.; supervision, M.B.M.; project administration, M.F.A.; funding acquisition, M.B.M. All authors have read and agreed to the published version of the manuscript.

Funding: This research was funded by Universiti Kebangsaan Malaysia (UKM), grant number MI-2019-013.

Acknowledgments: The authors are grateful to the Department of Environment Malaysia for the provided water quality data, and to the Laboratory of Chemical Oceanography, Faculty of Science and Technology, Universiti Kebangsaan Malaysia for the analysis of water samples, as well as to the water treatment plant authorities, i.e., Puncak Niaga (M) Sdn. Bhd. and Konsortium Air Selangor Sdn. Bhd. for allowing the collection of water samples from the outlets of their plants. The authors are also thankful to the Institute of Climate Change, UKM, for 
preparing the study area map through ArcGIS. The authors also acknowledge the suggestions of Che Abd Rahim Mohamed, Lubna Alam, and Goh Choo Ta.

Conflicts of Interest: The authors declare no conflict of interest.

\section{Appendix A}

Table A1. One-way ANOVA of Cd and Cr concentrations in drinking water supply chain, Langat Basin.

\begin{tabular}{cccccccc}
\hline \multirow{2}{*}{$\begin{array}{c}\text { Water Quality } \\
\text { Parameter }\end{array}$} & $\boldsymbol{M}$ & $\begin{array}{c}\text { Between } \\
\text { Groups }\end{array}$ & $\begin{array}{c}\text { Within } \\
\text { Groups }\end{array}$ & Total & $\begin{array}{c}\text { Between } \\
\text { Groups }\end{array}$ & $\begin{array}{c}\text { Within } \\
\text { Groups }\end{array}$ & $\boldsymbol{F}$ \\
\hline $\mathrm{Cd}$ & 138 & 14.6 & 23.6 & 38.1 & 489 & 0.2 & $27.6^{*}\left(p=5.99 \times 10^{-14}\right)$ \\
$\mathrm{Cr}$ & 138 & 1.5 & 5.1 & 6.6 & 0.5 & 0.04 & $13.1 *\left(p=1.56 \times 10^{-7}\right)$ \\
\hline
\end{tabular}

Table A2. Multiple comparisons of Cd (mg/L) and Cr (mg/L) means based on Tukey HSD (Honestly Significant Difference) test in drinking water supply chain at Langat River Basin, Malaysia.

\begin{tabular}{|c|c|c|c|c|c|c|c|}
\hline \multirow{2}{*}{$\begin{array}{l}\text { Dependent } \\
\text { Variable }\end{array}$} & \multirow{2}{*}{$\begin{array}{l}\text { (I) Drinking } \\
\text { Water Supply } \\
\text { Stages }\end{array}$} & \multirow{2}{*}{ (J) Drinking Water Supply Stages } & \multirow{2}{*}{$\begin{array}{c}\text { Mean } \\
\text { Difference } \\
\text { (I-J) }\end{array}$} & \multirow{2}{*}{$\begin{array}{l}\text { Standard } \\
\text { Error }\end{array}$} & \multirow{2}{*}{$\begin{array}{l}\text { Significance } \\
(p)\end{array}$} & \multicolumn{2}{|c|}{$\begin{array}{l}\text { 95\% Confidence } \\
\text { Interval }\end{array}$} \\
\hline & & & & & & $\begin{array}{l}\text { Lower } \\
\text { Bound }\end{array}$ & $\begin{array}{l}\text { Upper } \\
\text { Bound }\end{array}$ \\
\hline \multirow{12}{*}{$\mathrm{Cd}(\mathrm{mg} / \mathrm{L})$} & \multirow{3}{*}{ River } & Water treatment plant (WTP) & $0.80 *$ & 0.12 & $4.3 \times 10^{-9}$ & 0.49 & 1.12 \\
\hline & & Household tap & 0.80 * & 0.11 & $3.5 \times 10^{-11}$ & 0.53 & 1.08 \\
\hline & & Household water filtration system & $0.91 *$ & 0.11 & $6 \times 10^{-13}$ & 0.64 & 1.19 \\
\hline & \multirow{3}{*}{$\begin{array}{l}\text { Water treatment } \\
\text { plant }(\mathrm{WTP})\end{array}$} & River & $-0.80 *$ & 0.12 & $4.3 \times 10^{-9}$ & -1.12 & -0.49 \\
\hline & & Household tap & 0.003 & 0.11 & 1 & -0.28 & 0.27 \\
\hline & & Household water filtration system & 0.11 & 0.11 & 0.73 & -0.17 & 0.39 \\
\hline & \multirow{3}{*}{ Household tap } & River & $-0.80 *$ & 0.11 & $3.5 \times 10^{-11}$ & -1.08 & -0.53 \\
\hline & & water treatment plant (WTP) & 0.003 & 0.11 & 1 & -0.27 & 0.28 \\
\hline & & Household water filtration system & 0.11 & 0.09 & 0.58 & -0.12 & 0.34 \\
\hline & \multirow{3}{*}{$\begin{array}{c}\text { Household } \\
\text { water filtration } \\
\text { system }\end{array}$} & River & $-0.91 *$ & 0.11 & $6 \times 10^{-13}$ & -1.19 & -0.64 \\
\hline & & water treatment plant (WTP) & -0.11 & 0.11 & 0.73 & -0.39 & 0.17 \\
\hline & & Household tap & -0.11 & 0.09 & 0.58 & -0.34 & 0.12 \\
\hline \multirow{12}{*}{$\mathrm{Cr}(\mathrm{mg} / \mathrm{L})$} & \multirow{3}{*}{ River } & Water treatment plant (WTP) & $0.25 *$ & 0.06 & $9 \times 10^{-5}$ & 0.11 & 0.40 \\
\hline & & Household tap & 0.10 & 0.05 & 0.21 & -0.03 & 0.23 \\
\hline & & Household water filtration system & $0.26 *$ & 0.05 & $2 \times 10^{-6}$ & 0.14 & 0.39 \\
\hline & \multirow{3}{*}{$\begin{array}{c}\text { Water treatment } \\
\text { plant }(\mathrm{WTP})\end{array}$} & River & $-0.25 *$ & 0.06 & $9 \times 10^{-5}$ & -0.40 & -0.11 \\
\hline & & household tap & $-0.16^{*}$ & 0.05 & 0.01 & -0.28 & -0.03 \\
\hline & & Household water filtration system & 0.01 & 0.05 & 0.99 & -0.12 & 0.14 \\
\hline & \multirow{3}{*}{ Household tap } & River & -0.10 & 0.05 & 0.21 & -0.23 & 0.03 \\
\hline & & water treatment plant (WTP) & $0.16^{*}$ & 0.05 & 0.01 & 0.03 & 0.28 \\
\hline & & Household water filtration system & $0.17 *$ & 0.04 & $4.5 \times 10^{-4}$ & 0.06 & 0.27 \\
\hline & \multirow{3}{*}{$\begin{array}{l}\text { Household } \\
\text { water filtration } \\
\text { system }\end{array}$} & River & $-0.26 *$ & 0.05 & $2 \times 10^{-6}$ & -0.39 & -0.14 \\
\hline & & water treatment plant (WTP) & -0.01 & 0.05 & 0.995 & -0.14 & 0.12 \\
\hline & & Household tap & $-0.17 *$ & 0.04 & $4.5 \times 10^{-4}$ & -0.27 & -0.06 \\
\hline
\end{tabular}

Note: ${ }^{*}$ The mean difference is significant at the 0.05 level.

Table A3. Augmented Dickey-Fuller (ADF) unit root test for auto regression.

\begin{tabular}{ccccc}
\hline Variable & ADF with Constant & $p$-Value & ADF with Constant and Trend & $p$-Value \\
\hline $\mathrm{Cd}$ & -11.545 & $3.76 \times 10^{-17 *}$ & -11.714 & $2.6 \times 10^{-16 *}$ \\
$\mathrm{Cr}$ & -1.2599 & $6.5 \times 10^{1}$ & -3.2672 & $7.17 \times 10^{-2 *}$ \\
\hline
\end{tabular}

Note: * Significant at 0.05 level. 
Table A4. Auto regression for Cd Model $(t=115)$.

\begin{tabular}{ccccc}
\hline Variables & Coefficient & Standard Error & $\boldsymbol{t}$-Value & $p$-Value \\
\hline Constant & 1.02417 & 0.27284 & 3.754 & $0.0003^{* * *}$ \\
Lag 1 & -0.03538 & 0.09534 & -0.371 & 0.7113 \\
Lag 2 & 0.05592 & 0.09289 & 0.602 & 0.5485 \\
Lag 3 & -0.06715 & 0.09302 & -0.722 & 0.4719 \\
Lag 4 & 0.11769 & 0.09249 & 1.272 & 0.2060 \\
Lag 5 & -0.01826 & 0.09297 & -0.196 & 0.8446 \\
Lag 6 & -0.22229 & 0.09283 & -2.395 & $0.0184^{* * *}$ \\
Lag 7 & 0.22085 & 0.09525 & 2.319 & $0.0223^{* * *}$ \\
u (-6) & 0.20617 & 0.09257 & 2.227 & $0.0280^{* *}$ \\
\hline
\end{tabular}

Note: Lag (dependent variable); Lag 1 to 7 = first month to seventh month, respectively; $\mathrm{u}(-6)=$ auto generative weight; ${ }^{* * *}$ significant at 0.01 level. ${ }^{* *}$ significant at 0.05 level.

Table A5. Auto regression for Cr model $(t=124)$.

\begin{tabular}{ccccc}
\hline Variables & Coefficient & Standard Error & $\boldsymbol{t}$-Value & $\boldsymbol{p}$-Value \\
\hline Constant & 0.19268 & 0.09610 & 2.005 & $0.0472^{* *}$ \\
Lag 1 & 0.20961 & 0.06767 & 3.098 & $0.0024^{* * *}$ \\
Lag 2 & 0.64481 & 0.06699 & 9.626 & $1.25 \times 10$ - $^{* * *}$ \\
u (-2) & -0.47459 & 0.07912 & -5.998 & $2.13 \times 10^{-8 * *}$ \\
\hline
\end{tabular}

Note: Lag (dependent variable); Lag 1 = first month; Lag 2 = second month; $\mathrm{u}(-2)$ = auto generative weight; *** significant at 0.01 level; ** significant at 0.05 level.

Table A6. Auto regression for $\mathrm{Cd}$ model with external variables $(t=124)$.

\begin{tabular}{ccccc}
\hline Variables & Coefficient & Standard Error & $\boldsymbol{t}$-Ratio & $p$-Value \\
\hline Constant & 0.50945 & 0.39174 & 1.3005 & 0.1960 \\
Water flow & -0.00073 & 0.00162 & -0.4547 & 0.6502 \\
Rainfall & $-2.17297 \times 10^{-5}$ & 0.00013 & -0.1715 & 0.8641 \\
Temperature & 0.06835 & 0.03774 & 1.8109 & $0.0727^{*}$ \\
Lag 1 & -0.64645 & 0.13525 & -4.7796 & $5.15 \times 10^{-6 * * *}$ \\
Lag 2 & -0.40636 & 0.14763 & -2.7525 & $0.0069^{* * *}$ \\
Lag 3 & -0.26401 & 0.11146 & -2.3686 & $0.0195^{* *}$ \\
\hline
\end{tabular}

Dependent variable: Cd. ${ }^{* * *}$ significant at 0.01 level. ${ }^{* *}$ significant at 0.05 level. ${ }^{*}$ significant at 0.10 level.

Table A7. Auto regression for Cr model with external variables $(t=125)$.

\begin{tabular}{ccccc}
\hline Variables & Coefficient & Std. Error & $t$-Ratio & $p$-Value \\
\hline Constant & 9.44345 & 4.79696 & 1.9686 & $0.0513^{*}$ \\
\hline Water flow & -0.0129813 & 0.00862977 & -1.5042 & 0.1351 \\
\hline Rainfall & 0.000526234 & 0.000716295 & 0.7347 & 0.4640 \\
\hline Temperature & -0.321556 & 0.185214 & -1.7361 & $0.0851{ }^{*}$ \\
\hline Lag 2 & 0.305618 & 0.0831747 & 3.6744 & $0.0004^{* * *}$ \\
\hline \multicolumn{4}{c}{ Dependent variable: Cr. ${ }^{* * *}$ significant at 0.01 level. * significant at 0.10 level. }
\end{tabular}



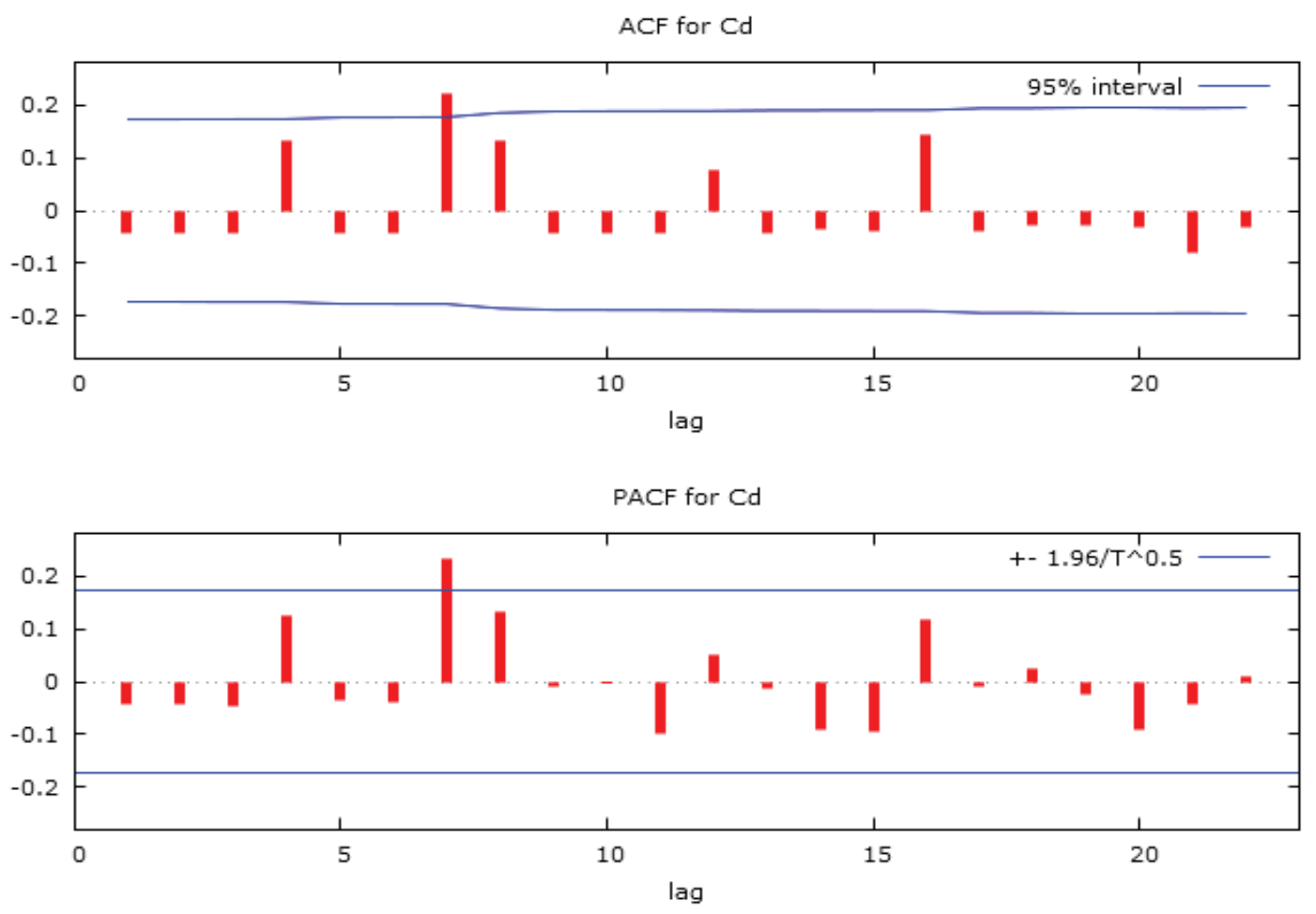

Figure A1. Auto correlation (ACF) and partial auto correlation (PACF) correlogram for Cd concentration.

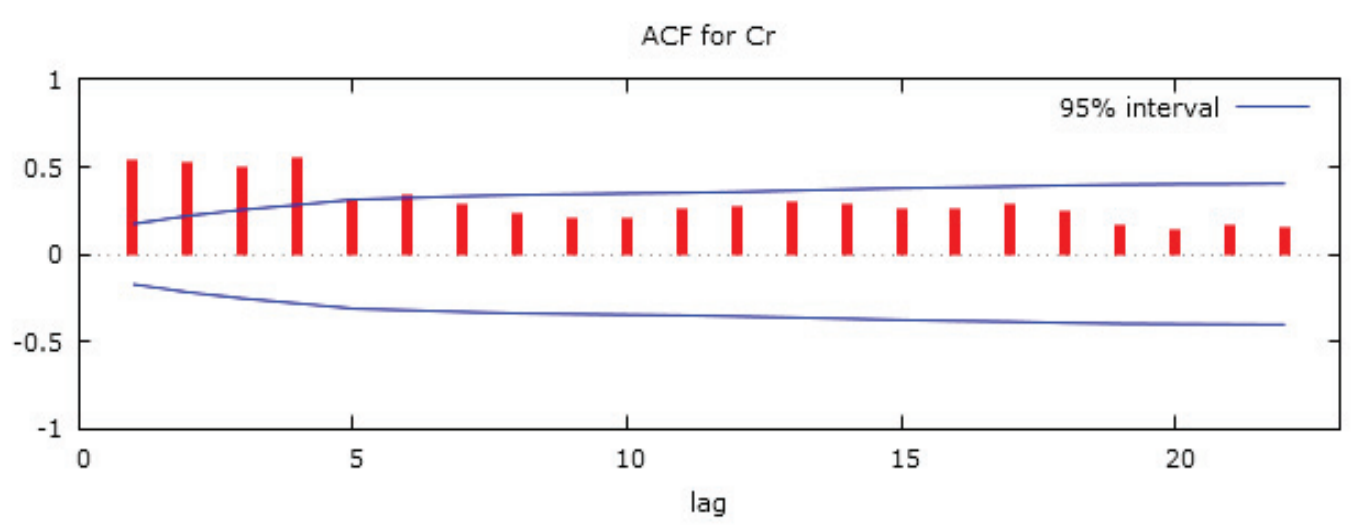

PACF for $\mathrm{Cr}$

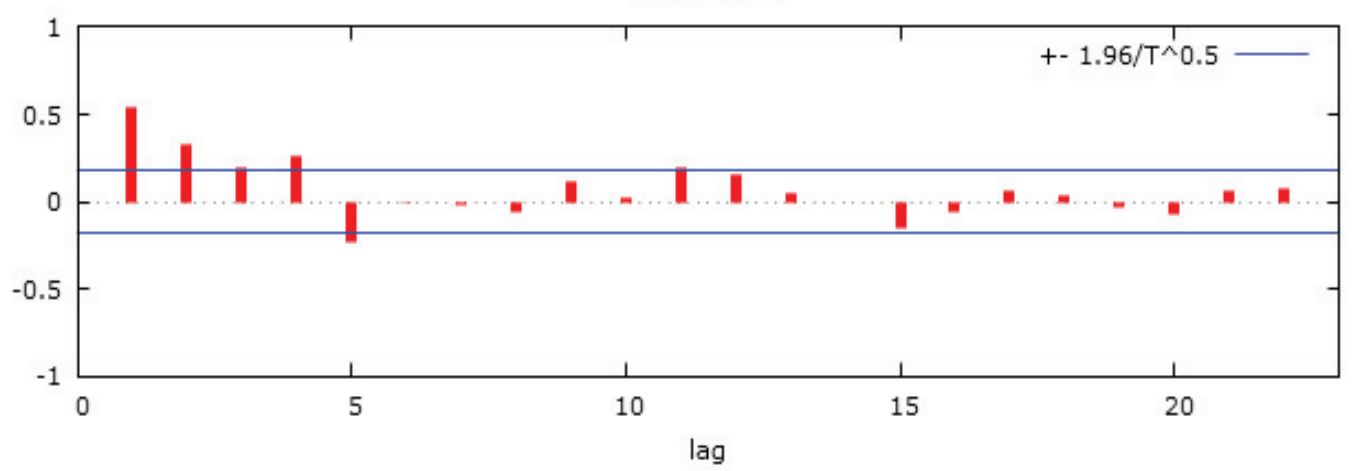

Figure A2. Auto correlation (ACF) and partial auto correlation (PACF) correlogram for Cr concentration. 


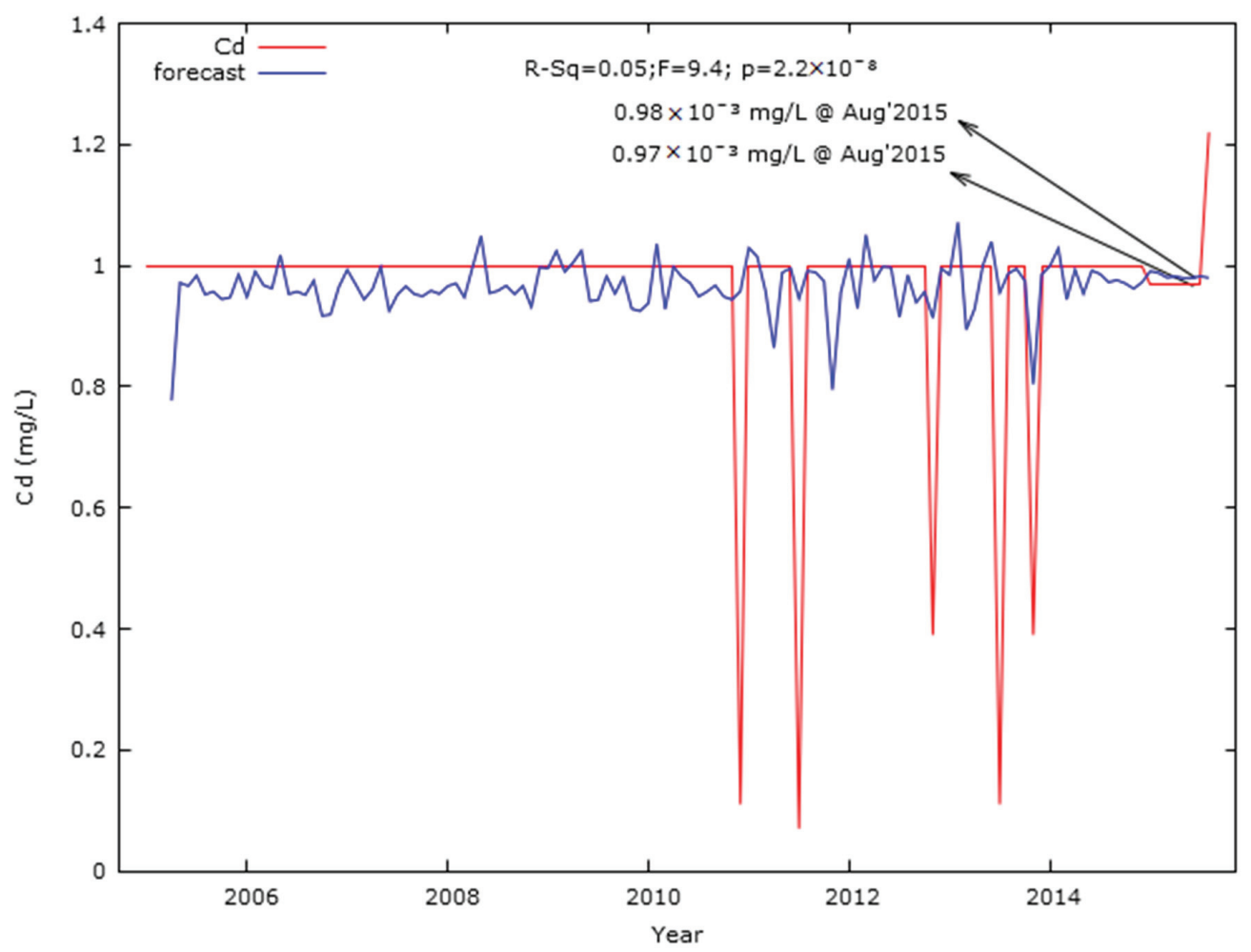

Figure A3. Forecast of $\mathrm{Cd}(\mathrm{mg} / \mathrm{L})$ concentration considering control variables in Langat River on the basis of auto-regressive analysis from 2005 to 2015. Note: $Y$-axis refers to Cd concentration in $\mathrm{mg} / \mathrm{L}$ and explains the determined and predicted $\mathrm{Cd}$ concentration considering the influences of environmental parameters.

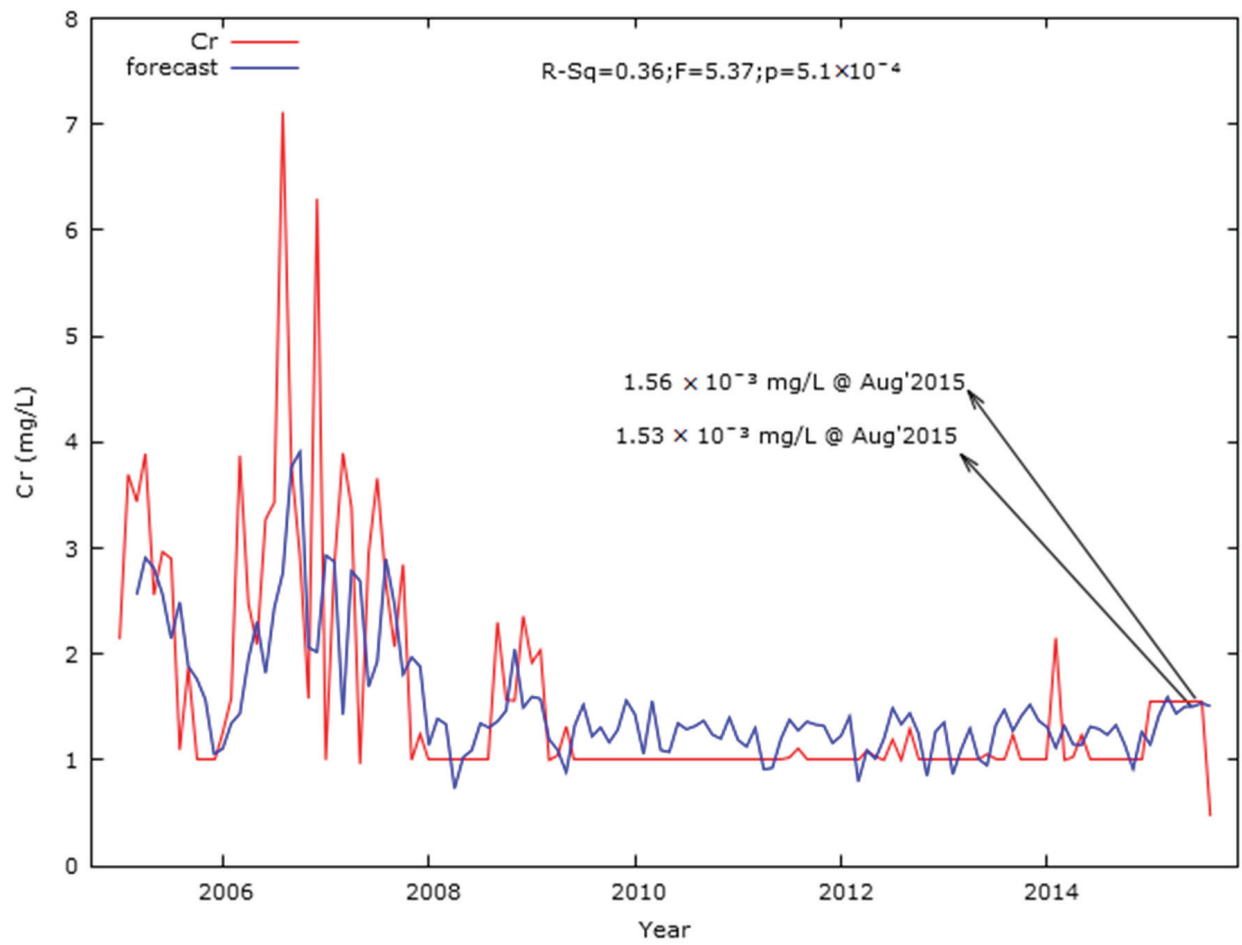

Figure A4. Forecast of $\mathrm{Cr}(\mathrm{mg} / \mathrm{L})$ concentration considering control variables in Langat River on the basis of auto-regressive analysis from 2005 to 2015 . Note: $Y$-axis refers to $\mathrm{Cr}$ concentration in $\mathrm{mg} / \mathrm{L}$ and explains the determined and predicted $\mathrm{Cr}$ concentration considering the influences of environmental parameters. 


\section{References}

1. United States Environmental Protection Agency. Secondary Drinking Water Standards: Guidance for Nuisance Chemicals; United States Environmental Protection Agency: Washington, DC, USA, 2017. Available online: https://www.epa.gov/dwstandardsregulations/secondary-drinking-water-standardsguidance-nuisance-chemicals (accessed on 18 December 2017).

2. Oze, C.; Bird, D.K.; Fendorf, S. Genesis of hexavalent chromium from natural sources in soil and groundwater. Proc. Natl. Acad. Sci. USA 2007, 104, 6544-6549. [CrossRef]

3. Ahmed, M.F.; Mokhtar, M.B.; Alam, L.; Mohamed, C.A.R.; Ta, G.C. Non-carcinogenic Health Risk Assessment of Aluminium Ingestion Via Drinking Water in Malaysia. Expo. Health 2019, 11, 167-180. [CrossRef]

4. Ahmed, M.F.; Alam, L.; Mohamed, C.A.R.; Mokhtar, M.; Ta, G.C. Health risk of Polonium 210 ingestion via drinking water: An experience of Malaysia. Int. J. Environ. Res. Public Health 2018, 15, 2056. [CrossRef]

5. Ahmed, M.F.; Alam, L.; Ta, G.C.; Mohamed, C.A.R.; Mokhtar, M. A Review on the Environmental Pollution of Langat River, Malaysia. Asian J. Water Environ. Pollut. 2016, 13, 25-31. [CrossRef]

6. Ahmed, M.F.; Alam, L.; Ta, G.C.; Mohamed, C.A.R.; Mokhtar, M. A Review on the Chemical Pollution of Langat River, Malaysia. Asian J. Water Environ. Pollut. 2016, 13, 9-15. [CrossRef]

7. Islam, M.S.; Ahmed, M.K.; Raknuzzaman, M.; Habibullah-Al-Mamun, M.; Islam, M.K. Heavy metal pollution in surface water and sediment: A preliminary assessment of an urban river in a developing country. Ecol. Indic. 2015, 48, 282-291. [CrossRef]

8. Mohiuddin, K.M.; Ogawa, Y.Z.H.M.; Zakir, H.M.; Otomo, K.; Shikazono, N. Heavy metals contamination in water and sediments of an urban river in a developing country. Int. J. Environ. Sci. Technol. 2011, 8, 723-736. [CrossRef]

9. Aris, A.Z.; Lim, W.Y.; Looi, L.J. Natural and Anthropogenic Determinants of Freshwater Ecosystem Deterioration: An Environmental Forensic Study of the Langat River Basin, Malaysia. In Environ. Management of River Basin Ecosystems; Ramkumar, M., Ed.; Springer: Berlin/Heidelberg, Germany, 2015; pp. 455-476.

10. Al-Badaii, F.; Shuhaimi-Othman, M. Heavy metals and water quality assessment using multivariate statistical techniques and water quality index of the Semenyih River, Peninsular Malaysia. Iranica J. Energy Environ. 2014, 5, 132-145. [CrossRef]

11. Mamun, A.A.; Hafizah, S.N.; Alam, M.Z. Improvement of existing water quality index in Selangor, Malaysia. In Proceedings of the 2nd International Conference on Water \& Flood Management (ICWFM-2009), Institute of Water and Flood Management, Bangladesh University of Engineering and Technology (BUET), Dhaka, Bangladesh, 15-17 March 2009.

12. Sarmani, S.B. The Determination of Heavy Metals in Water, Suspended Materials and Sediments from Langat River, Malaysia Sediment/Water Interactions; Springer: Berlin/Heidelberg, Germany, 1989; pp. 233-238.

13. Yusuf, M.A. River Water Quality and Ecosystem Health in Langat River Basin, Selangor, Malaysia. Ph.D. Thesis, Universiti Kebangsaan Malaysia, UKM Bangi, Malaysia, 2001.

14. Wang, J.; Liu, G.; Liu, H.; Lam, P.K. Multivariate statistical evaluation of dissolved trace elements and a water quality assessment in the middle reaches of Huaihe River, Anhui, China. Sci. Total Environ. 2017, 583, 421-431. [CrossRef]

15. United States Environment Protection Agency. National Primary Drinking Water Regulations. Ground Water and Drinking Water; United States Environment Protection Agency: Washington, DC, USA, 2017. Available online: https://www.epa.gov/ground-water-and-drinking-water/national-primary-drinkingwater-regulations (accessed on 28 February 2017).

16. Nalatambi, S. Determination of metals in tap water using atomic absorption spectrometry: A case study in bandar Sunway residential area. Sunway Acad. J. 2009, 6, 33-46.

17. Ong, C.; Ibrahim, S.; Sen, G.B. A survey of tap water quality in Kuala Lumpur. Urban Water J. 2007, 4, $29-41$. [CrossRef]

18. Azlan, A.; Khoo, H.E.; Idris, M.A.; Ismail, A.; Razman, M.R. Evaluation of minerals content of drinking water in Malaysia. Sci. World J. 2012. [CrossRef] [PubMed]

19. Ahmed, M.F.; Alam, L.; Ta, G.C.; Mohamed, C.A.R.; Mokhtar, M. A Preliminary Study to Investigate the Trace Metals in Drinking Water Supply Chain. In Proceedings of the In-house Seminar of the Chemical Oceanography Laboratory (ISSN: 0127-9629), Bangi, Malaysia, 2 June 2016. 
20. Ahmed, M.F.; Mokhtar, M.; Alam, L.; Ta, G.C.; Lee, K.E.; Khalid, R.M. Recognition of Local Authority for Better Management of Drinking Water at the Langat River Basin, Malaysia. Int. J. Eng. Technol. 2018, 7, 148-154. [CrossRef]

21. Mokhtar, M.B.; Toriman, M.E.H.; Hossain, A.A. Social learning in facing challenges of sustainable development: A case of Langat River Basin, Malaysia. Res. J. Appl. Sci. 2010, 5, 434-443.

22. Mokhtar, M.B.; Toriman, M.E.H.; Hossain, M.; Abraham, A.; Tan, K.W. Institutional challenges for integrated river basin management in Langat River Basin, Malaysia. Water Environ. J. 2011, 25, 495-503. [CrossRef]

23. Satarug, S.; Nishijo, M.; Ujjin, P.; Moore, M.R. Chronic exposure to low-level cadmium induced zinc-copper dysregulation. J. Trace Elem. Med. Biol. 2018, 46, 32-38. [CrossRef]

24. Prince, M.; Wimo, A.; Guerchet, M.; Gemma-Claire, A.; Wu, Y.T.; Prina, M. World Alzheimer Report 2015: The Global Impact of Dementia-An analysis of prevalence, incidence, cost and trends. Alzheimer's Dis. Int. 2015. [CrossRef]

25. García-Esquinas, E.; Pollan, M.; Tellez-Plaza, M.; Francesconi, K.A.; Goessler, W.; Guallar, E.; Umans, J.G. Cadmium Exposure and Cancer Mortality in a Prospective Cohort: The Strong Heart Study. Env. Health Perspect 2014. [CrossRef]

26. McCredie, M.; Stewart, J.H. Risk factors for kidney cancer in New South Wales. IV. Occupation. Br. J. Ind. Med. 1993, 50, 349-354. [CrossRef]

27. Kolonel, L.N. Association of cadmium with renal cancer. Cancer 1976, 37, 1782-1787. [CrossRef]

28. Boffetta, P.; Fontana, L.; Stewart, P.; Zaridze, D.; Szeszenia-Dabrowska, N.; Janout, V.; Bencko, V. Occupational exposure to arsenic, cadmium, chromium, lead and nickel, and renal cell carcinoma: A case-control study from Central and Eastern Europe. Occup. Environ. Med. 2011, 68, 723-728. [CrossRef] [PubMed]

29. Pesch, B.; Haerting, J.; Ranft, U.; Klimpel, A.; Oelschlagel, B.; Schill, W. Occupational risk factors for renal cell carcinoma: Agent-specific results from a case-control study in Germany. MURC Study Group. Multicenter urothelial and renal cancer study. Int. J. Epidemiol. 2000, 29, 1014-1024. [CrossRef]

30. Partanen, T.; Heikkila, P.; Hernberg, S.; Kauppinen, T.; Moneta, G.; Ojajarvi, A. Renal cell cancer and occupational exposure to chemical agents. Scand. J. Work Environ. Health 1991, 17, 231-239. [CrossRef]

31. IARC. IARC Monographs on the Evaluation of Carcinogenic Risks to Humans; Beryllium, Cadmium, Mercury, and Exposures in the Glass Manufacturing Industry: Geneva, Switzerland, 1993.

32. IARC. IARC Monographs on the Evaluation of the Carcinogenic Risks to Humans; International Agency for Research on Cancer: Lyon, France, 2017. Available online: http://monographs.iarc.fr/ENG/Classification/ latest_classif.php (accessed on 8 December 2017).

33. Järup, L.; Berglund, M.; Elinder, C.G.; Nordberg, G.; Vahter, M. Health effects of cadmium exposure- a review of the literature and a risk estimate. Scand. J. Work Environ. Health 1998, 24 (Suppl. 1), 1-51.

34. Song, J.K.; Luo, H.; Yin, X.H.; Huang, G.L.; Luo, S.Y.; Lin, D.R.; Yuan, D.B. Association between cadmium exposure and renal cancer risk: A meta-analysis of observational studies. Sci. Rep. 2015, 5, 17976. [CrossRef] [PubMed]

35. Hotz, P.; Buchet, J.P.; Bernard, A.; Lison, D.; Robert, L. Renal effects of low-level environmental cadmium exposure: 5-year follow-up of a subcohort from the Cadmibel study. Lancet 1999, 354, 1508-1513. [CrossRef]

36. Wu, H.; Liao, Q.; Chillrud, S.N.; Yang, Q.; Huang, L.; Bi, J.; Yan, B. Environmental Exposure to Cadmium: Health Risk Assessment and its Associations with Hypertension and Impaired Kidney Function. Sci. Rep. 2016, 6. [CrossRef]

37. World Health Organization. Preventing Disease through Healthy Environments Exposure to Cadmium: A Major Public Health Concern; World Health Organization: Geneva, Switzerland, 2010. Available online: http://www.who.int/ipcs/features/cadmium.pdf (accessed on 8 December 2017).

38. World Health Organization. Cadmium. Environ. Health Criteria; World Health Organization: Geneva, Switzerland, 1992; Volume 134. Available online: http://www.inchem.org/documents/ehc/ehc/ehc134.htm (accessed on 29 May 2017).

39. Mandel, J.S.; McLaughlin, J.K.; Schlehofer, B.; Mellemgaard, A.; Helmert, U.; Lindblad, P.; McCredie, M. International renal-cell cancer study. IV. Occupation. Int. J. Cancer 1995, 61, 601-605. [CrossRef]

40. Järup, L. Hazards of heavy metal contamination. Br. Med Bull. 2003, 68, 167-182. [CrossRef]

41. Agency for Toxic Substances and Disease Registry. Cadmium Toxicity, What Diseases are Associated with Chronic Exposure to Cadmium? Agency for Toxic Substances and Disease Registry: Atlanta, GA, USA, 2013. Available online: http://www.atsdr.cdc.gov/csem/csem.asp?csem=6\&po=12 (accessed on 18 March 2015). 
42. Industrial Injuries Advisory Council. Cadmium and Genito-Urinary Cancers; Industrial Injuries Advisory Council, Department for Work and Pensions: London, UK, 2009. Available online: https:// www.gov.uk/government/uploads/system/uploads/attachment_data/file/328543/iiac-pp24.pdf (accessed on 20 December 2017).

43. Il'yasova, D.; Schwartz, G.G. Cadmium and renal cancer. Toxicol. Appl. Pharmacol. 2005, 207, $179-186$. [CrossRef]

44. Armstrong, B.G.; Kazantzis, G. Prostatic cancer and chronic respiratory and renal disease in British cadmium workers: A case control study. Br. J. Ind. Med. 1985, 42, 540-545. [CrossRef] [PubMed]

45. Zhitkovich, A. Chromium in drinking water: Sources, metabolism, and cancer risks. Chem. Res. Toxicol. 2011, 24, 1617-1629. [CrossRef] [PubMed]

46. United States Environmental Protection Agency. Toxicological Review of Hexavalent Chromium; United States Environmental Protection Agency: Washington, DC, USA, 2010. Available online: https://ofmpub.epa.gov/ eims/eimscomm.getfile?p_download_id=498828 (accessed on 24 February 2018).

47. IARC. Chromium, Nickel and Welding, IARC Monographs on the Evaluation of Carcinogenic Risks to Humans; International Agency for Research on Cancer: Lyon, French, 1990. Available online: https://monographs.iarc. fr/ENG/Monographs/vol49/mono49.pdf (accessed on 24 February 2018).

48. Water Boards. Frequently Asked Questions about Hexavalent Chromium in Drinking Wate; Water Boards: Sacramento, CA, USA, 2015. Available online: https://www.waterboards.ca.gov/drinking_water/certlic/ drinkingwater/documents/chromium6/chromium_fact_sheet_2015_final.pdf (accessed on 24 February 2018).

49. World Health Organization. Chromium in Drinking-Water; World Health Organization: Geneva, Switzerland, 2003. Available online: http://www.who.int/water_sanitation_health/dwq/chemicals/chromium.pdf (accessed on 24 February 2018).

50. Agency for Toxic Substances and Disease Registry. Toxicological Profile of Chromium; U.S. Department of Health and Human Services, Agency for Toxic Substances and Disease Registry: Washington, DC, USA, 2012. Available online: https://www.atsdr.cdc.gov/toxprofiles/tp7.pdf (accessed on 24 February 2018).

51. Federal-Provincial-Territorial Committee on Drinking Water. Chromium in Drinking Water; Federal-Provincial-Territorial Committee on Drinking Water, Canada. 2015. Available online: http://www.healthycanadians.gc.ca/health-system-systeme-sante/consultations/chromium-chrome/ alt/chromium-chrome-eng.pdf (accessed on 24 February 2018).

52. American Water Works Association. Chromium in Drinking Water: A Technical Information Primer; American Water Works Association: Denver, CO, USA, 2013.

53. Pellerin, C.; Booker, S.M. Reflections on hexavalent chromium: Health hazards of an industrial heavyweight. Environ. Health Perspect. 2000, 108, 402. [CrossRef] [PubMed]

54. Occupational Safety and Health Administration. Occupational Exposure to Hexavalent Chromium, Final Rule; Occupational Safety and Health Administration (OSHA), United States Department of Labor: Washington, DC, USA, 2006. Available online: https://www.osha.gov/pls/oshaweb/owadisp.show_document?p_id= 18599\&p_table=federal_register (accessed on 24 February 2018).

55. CDC. Occupational Exposure to Hexavalent Chromium; Centers for Disease Control and Prevention National Institute for Occupational Safety and Health: Washington, DC, USA, 2013. Available online: https: //www.cdc.gov/niosh/docs/2013-128/pdfs/2013_128.pdf (accessed on 24 February 2018).

56. Beaumont, J.J.; Sedman, R.M.; Reynolds, S.D.; Sherman, C.D.; Li, L.H.; Howd, R.A.; Alexeeff, G.V. Cancer mortality in a Chinese population exposed to hexavalent chromium in drinking water. Epidemiology 2008, 19, 12-23. [CrossRef] [PubMed]

57. Deamer, K. Chromium-6 in Tap Water: Why the 'Erin Brockovich' Chemical Is Dangerous. LiveScience 2016. Available online: https://www.livescience.com/56210-what-is-chromium-6-in-tap-water.html (accessed on 24 February 2018).

58. Stern, A.H. A quantitative assessment of the carcinogenicity of hexavalent chromium by the oral route and its relevance to human exposure. Environ. Res. 2010, 110, 798-807. [CrossRef]

59. LENNTECH. Chromium (Cr) and Water; LENNTECH: Miami Beach, FL, USA, 2018. Available online: https: //www.lenntech.com/periodic/water/chromium/chromium-and-water.htm (accessed on 24 February 2018).

60. CWA. The Dangers of Hexavalent Chromium (Chromium 6) in California Drinking Water; Clean Water Action: Washington, DC, USA, 2018. Available online: https://www.cleanwateraction.org/features/dangershexavalent-chromium-chromium-6-california-drinking-water (accessed on 24 February 2018). 
61. Daud, Z.; Mohamed, C.A.R. Preliminary Studies on Distribution and Behavior of Rare Earth Elements in the Sungai Balok, Kuantan. In Advancements in Marine and freshwater Sciences Int. Symposium; Universiti Malaysia Terengganu: Terengganu, Malaysia, 2013.

62. Paulson, A.J.; Curl, H.C.; Feely, R.A.; Krogslund, K.A.; Hanson, S. Trace Metal and Ancillary Data in Puget Sound: August 1986: Data report (No. PB-91-201590/XAB); Pacific Marine Environmental Lab.: Seattle, WA, USA, 1991.

63. United States Environmental Protection Agency. Guidance for Data Useability in Risk Assessment (Part A); United States Environmental Protection Agency: Washington, DC, USA, 1991. Available online: https://rais.ornl.gov/documents/USERISKA.pdf (accessed on 7 December 2017).

64. Ab Razak, N.H.; Praveena, S.M.; Aris, A.Z.; Hashim, Z. Quality of Kelantan drinking water and knowledge, attitude and practice among the population of Pasir Mas, Malaysia. Public Health 2016. [CrossRef]

65. United States Environmental Protection Agency. Risk Assessment Guidance for Superfund; Volume I Human Health Evaluation Manual (Part A). Risk Assessment Guidance for Superfund. Volume I Human Health Evaluation Manual (Part A) EPA/540/1-89/002; United States Environmental Protection Agency: Washington, DC, USA, 1989.

66. United States Environmental Protection Agency. IRIS Assessments; United States Environmental Protection Agency: Washington, DC, USA, 2016. Available online: https://cfpub.epa.gov/ncea/iris2/atoz.cfm (accessed on 17 November 2017).

67. USEPA. Regional Screening Levels (RSLs)—Generic Tables (November 2017). United States Environmental Protection Agency; 2017. Available online: https://semspub.epa.gov/work/HQ/197025.pdf (accessed on 17 November 2017).

68. United States Environmental Protection Agency DOS. Population Distribution by Local Authority Areas and Mukims 2010; Department of Statistics: Putrajaya, Malaysia, 2013. Available online: http://newss.statistics. gov.my/newss-portalx/ep/epProductFreeDownloadSearch.seam (accessed on 15 September 2015).

69. Yamane, T. Statistics, An Introductory Analysis, 2nd ed.; Harper and Row: New York, NY, USA, 1967.

70. Alam, M.M. Linkages between Climatic Changes and Food Security among the Poor and Low-Income households in the East Coast Economic Region (ECER), Malaysia. Ph.D. Thesis, Universiti Kebangsaan Malaysia, Bangi, Malaysia, 2014.

71. Brockwell, P.J.; Davis, R.A. Introduction to Time Series and Forecasting; Springer: Berlin/Heidelberg, Germany, 2016.

72. Hamilton, J.D. Time Series Analysis; Princeton University Press: Princeton, NJ, USA, 1994; Volume 2.

73. Cox, D.R.; Gudmundsson, G.; Lindgren, G.; Bondesson, L.; Harsaae, E.; Laake, P.; Lauritzen, S.L. Statistical analysis of time series: Some recent developments. Scandinavian J. Stat. 1981, 8, 93-115.

74. MOH. Drinking Water Quality Standard; Engineering Services Division, Ministry of Health, Malaysia: Putrajaya, Malaysia, 2010. Available online: http://kmam.moh.gov.my/public-user/drinking-water-qualitystandard.html (accessed on 25 February 2018).

75. United States Environmental Protection Agency. National Recommended Water Quality Criteria-Aquatic Life Criteria Table; United States Environmental Protection Agency: Washington, DC, USA, 2016.

76. European Commission. Quality Standard for Priority Substances and Certain other Pollutants, Directive 2013/39/EU of the European Parliament and of the Council of 12 August 2013 (amending Directives 2000/60/EC and 2008/105/EC as regards priority substances in the field of water policy, L 226/1); Official Journal of the European Union, European Commission: Brussels, Belgium, 2013.

77. United States Environmental Protection Agency. Ground Water and Drinking Water; United States Environmental Protection Agency: Washington, DC, USA, 2016. Available online: https://www.epa. gov/aboutepa/mailing-addresses-and-phone-numbers\#HQ (accessed on 28 February 2017).

78. WHO. Guidelines for Drinking-Water Quality: Fourth Edition Incorporating the First Addendum; World Health Organization: Geneva, Switzerland, 2017. Available online: http://apps.who.int/iris/bitstream/10665/254637/ 1/9789241549950-eng.pdf?ua=1 (accessed on 29 May 2017).

79. Agency for Toxic Substances and Disease Registry. Public Health Statement for Aluminum; Agency for Toxic Substances and Disease Registry: Atlanta, GA, USA, 2008. Available online: https://www.atsdr.cdc.gov/phs/ phs.asp?id=1076\&tid=34 (accessed on 18 December 2017).

80. Shazili, N.A.M.; Yunus, K.; Ahmad, A.S.; Abdullah, N.; Rashid, M.K.A. Heavy metal pollution status in the Malaysian aquatic environment. Aquat. Ecosyst. Health Manag. 2006, 9, 137-145. [CrossRef] 
81. Al-Badaii, F.; Halim, A.A.; Shuhaimi-Othman, M. Evaluation of dissolved heavy metals in water of the Sungai Semenyih (Peninsular Malaysia) using environmetric methods. Sains Malays. 2016, 45, 841-852.

82. APEC. Are There Any Potential Health Risks Associated with Corrosion Byproducts from Water Transported Through Galvanized Drinking Water Pipes? APEC Water Systems: City of Industry, CA, USA, 2017. Available online: http://www.freedrinkingwater.com/water_health/health2/corrosion-byproducts2galvanized-drinking-pipes-health-risks.htm (accessed on 15 May 2017).

83. United States Environmental Protection Agency. Chromium in Drinking Water; United States Environmental Protection Agency: Washington, DC, USA, 2018. Available online: https://www.epa. gov/dwstandardsregulations/chromium-drinking-water (accessed on 24 February 2018).

84. STI. Fabrication Factors for Carbon Steel Pipe Vs. Stainless Steel Pipe. STI Group. 2016. Available online: http://setxind.com/fabrication/fabrication-factors-carbon-steel-pipe-vsstainless-steel-pipe/ (accessed on 15 May 2017).

85. Thomasnet. Stainless Steel Pipe Types; Thomas Publishing Company: New York, NY, USA, 2017. Available online: http://www.thomasnet.com/articles/pumps-valves-accessories/stainless-steelpipe-types (accessed on 14 May 2017).

86. Cho, R. Chromium-6 Found in Tap Water of 31 U.S. Cities; Earth Institute, Columbia University: New York, NY, USA, 2010. Available online: http://blogs.ei.columbia.edu/2010/12/30/chromium-6-found-in-tap-water-of31-u-s-cities/ (accessed on 24 February 2018).

87. Chebeir, M.; Chen, G.; Liu, H. Emerging investigators series: Frontier review: Occurrence and speciation of chromium in drinking water distribution systems. Environ. Sci. Water Res. Technol. 2016, 2, 906-914. [CrossRef]

88. Daschner, F.; Rüden, H.; Simon, R.; Clotten, J. Microbiological contamination of drinking water in a commercial household water filter system. Eur. J. Clin. Microbiol. Infect. Dis. 1996, 15, 233-237. [CrossRef] [PubMed]

89. Fiore, J.; Babineau, R. Effect of an activated carbon filter on the microbial quality of water. Appl. Environ. Microbiol. 1977, 34, 541-546. [CrossRef]

90. PEI. Chelation, Uptake, and Binding of Trace Metals; The Princeton Environmental Institute: Princeton, NJ, USA, 2000. Available online: https://www.princeton.edu/ \{\}cebic/chelbindintro.html (accessed on 25 May 2017).

91. Wallis, C.; Stagg, C.H.; Melnick, J.L. The hazards of incorporating charcoal filters into domestic water systems. Water Res. 1974, 8, 111-113. [CrossRef]

92. Walsh, K. Treating Bacteria in Drinking Water; Scranton Gillette Communications: Arlington Heights, IL, USA, 2009. Available online: https://www.wqpmag.com/treating-bacteria-drinking-water (accessed on 25 May 2017).

93. Hashim, N.; Yusop, H. Drinking water quality of water vending machines in Parit Raja, Batu Pahat, Johor. In IOP Conference Series: Materials Science and Engineering; IOP Publishing: Bristol, UK, 2016.

94. WHO. Guidelines for Drinking-Water Quality, 4th ed.; World Health Organization: Geneva, Switzerland, 2011. Available online: http://apps.who.int/iris/bitstream/10665/44584/1/9789241548151_eng.pdf (accessed on 8 December 2017).

95. Frey, M.; Seidel, C.; Edwards, M.; Parks, J. Occurrence Survey of Boron and Hexavalent Chromium; American Water Works Association: Denver, CO, USA, 2005.

96. Brandhuber, P. Low-Level Hexavalent Chromium Treatment Options; American Water Works Association: Denver, CO, USA, 2004.

97. United States Environmental Protection Agency. A Regulators' Guide to the Management of Radioactive Residuals from Drinking Water Treatment Technologies; United States Environmental Protection Agency: Washington, DC, USA, 2005. Available online: https://www.epa.gov/sites/production/files/2015-05/documents/816-r-05-004. pdf (accessed on 30 May 2017).

(C) 2020 by the authors. Licensee MDPI, Basel, Switzerland. This article is an open access article distributed under the terms and conditions of the Creative Commons Attribution (CC BY) license (http://creativecommons.org/licenses/by/4.0/). 